\title{
A Review of Analytical Methods USED IN GeOGRAPHIC ORIGIN Determination OF GeMStOneS
}

\author{
Lee A. Groat, Gaston Giuliani, Jennifer Stone-Sundberg, Ziyin Sun, Nathan D. Renfro, and Aaron C. Palke
}

Origin determination is of increasing importance in the gem trade. It is possible because there is a close relationship between the geological environment of formation and the physical and chemical properties of gemstones, such as trace element and isotopic compositions, that can be measured in the laboratory using combinations of increasingly sophisticated instrumentation. Origin conclusions for ruby, sapphire, and emerald make up the bulk of demand for these services, with growing demand for alexandrite, tourmaline, and spinel. However, establishing origin with a high degree of confidence using the capabilities available today is met with varying degrees of success. Geographic origin can be determined with a high level of confidence for materials such as emerald, Paraíba-type tourmaline, alexandrite, and many rubies. For some materials, especially blue sapphire and some rubies, the situation is more difficult. The main problem is that if the geology of two deposits is similar, then the properties of the gemstones they produce will also be similar, to the point where concluding an origin becomes seemingly impossible in some cases. Origin determination currently relies on a combination of traditional gemological observations and advanced analytical instrumentation.

n gemology, "origin" refers to the geographic locality of a gemstone deposit (Hänni, 1994). Origin determination of colored gemstones began with Gübelin and SSEF (both in Switzerland) in the 1950s and with AGL (New York) in 1977 (Schwarz, 2015). Origin determination is of increasing importance in today's market, and for many gems this information is considered either a value-adding factor or a positive for the salability of a gemstone (Hainschwang and Notari, 2015).

Origin determination is often possible because there is a close relationship between the environment of crystallization, especially the mineralogical and chemical composition of the host rock, and the properties of the gemstones that can be studied in the lab, often using sophisticated equipment (Hänni, 1994). In this paper we review the analytical techniques (figure 1) commonly used to characterize gem materials, with a specific focus on geographic origin determination. We also review the physical and chemical properties of corundum and emerald,

See end of article for About the Authors and Acknowledgments.

Gems \& GemOlogr, Vol. 55, No. 4, pp. 512-535,

http://dx.doi.org/10.5741/GEMS.55.4.512

(C) 2019 Gemological Institute of America which have the greatest demand for origin determination. Finally, we provide examples of origin determination of corundum and emerald from the literature to illustrate how these analytical methods are applied to the problem of establishing origin.

\section{In Brief}

- Origin determination is possible because there is a close relationship between the geological environment of formation and the physical and chemical properties of gemstones.

- Geographic origin can be determined with a high degree of confidence for emerald, Paraíba-type tourmaline, alexandrite, and many rubies.

- For some materials, especially blue sapphire and some rubies, the situation is more difficult.

\section{CHARACTERISTICS OF CORUNDUM}

Corundum, $\mathrm{Al}_{2} \mathrm{O}_{3}$, crystallizes in the $\overline{3} 2 / \mathrm{m}$ class of the trigonal system (space group $R \overline{3} c$ ) with hexagonal unit cell axes of $a \approx 4.76 \AA$ and $c \approx 12.99 \AA$ (Cesbron et al., 2002). This uniaxial negative material $\left(\mathrm{n}_{\omega}=\right.$ 


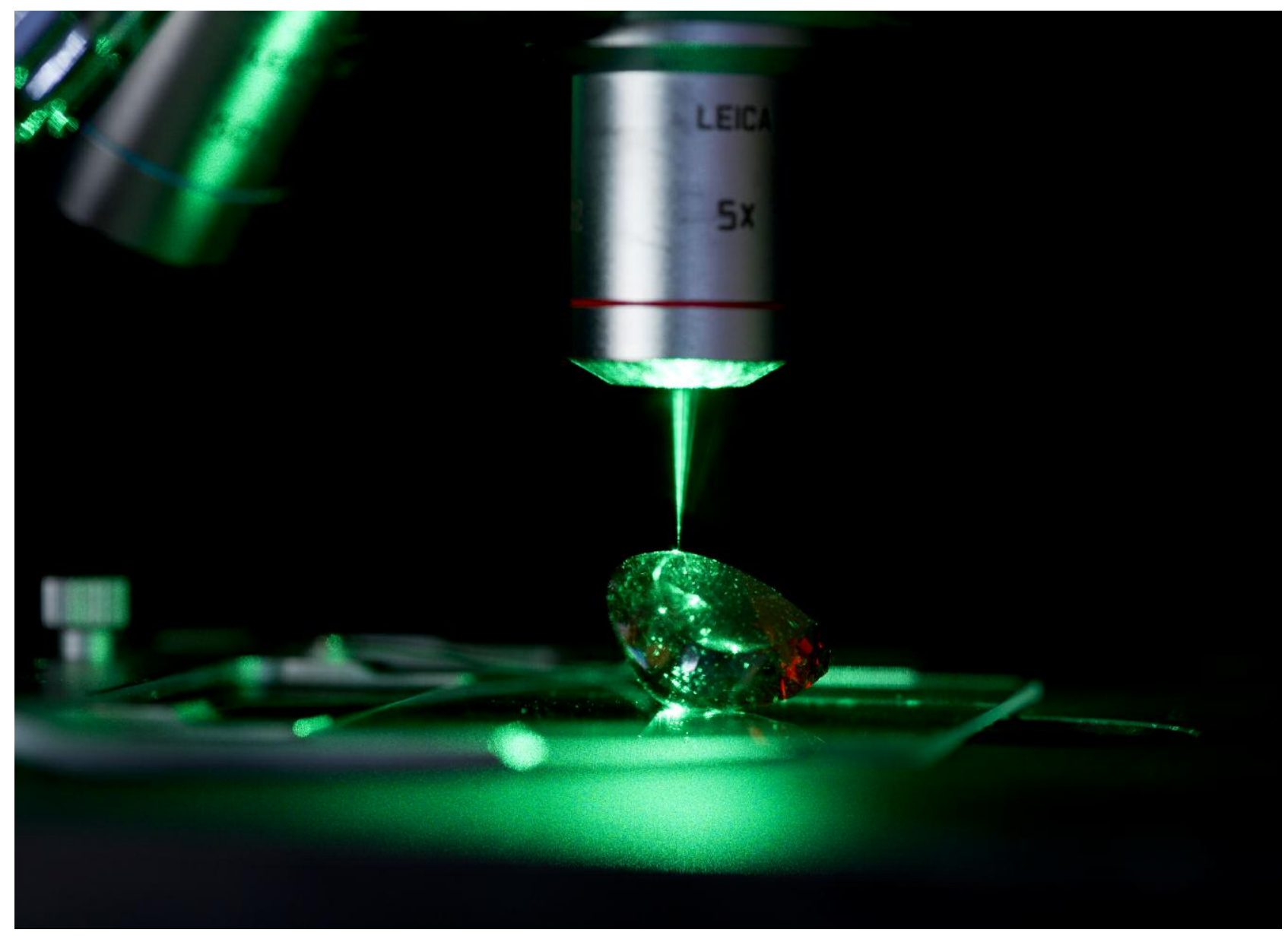

Figure 1. Confocal Raman spectroscopy, which can be used to identify mineral inclusions in gems submitted to the $1 a b$, is one of the advanced analytical methods used in geographic origin research. Photo by Kevin Schumacher.

$1.767-1.772$ and $\mathrm{n}_{\varepsilon} \approx 1.759-1.763$ ) has a specific gravity of approximately 4 . In corundum, the oxygen $(\mathrm{O})$ anions are in a hexagonal close-packed configuration and form layers of ions arranged successively in the order ABAB...etc. (figure 2). The aluminum (Al) atoms are coordinated by six $\mathrm{O}$ atoms, three from layer A and three from layer B, in a slightly distorted octahedral arrangement. Because there are two $\mathrm{Al}$ atoms for three atoms of $\mathrm{O}$, two $\mathrm{Al}$ sites out of every three are occupied, and one is vacant. A number of elements can substitute for $\mathrm{Al}^{3+}$ at the octahedral site $\left(\mathrm{Mg}^{2+}, \mathrm{Ti}^{4+}, \mathrm{V}^{3+}, \mathrm{Cr}^{3+}, \mathrm{Mn}^{2+}, \mathrm{Fe}^{2+, 3+}, \mathrm{Ga}^{3+}\right)$.

Euhedral crystals of corundum can exhibit different faces that correspond to a number of crystalline forms (Cesbron et al., 2002) (figure 3): the rhombohedron (positive, $\{10 \overline{1} 1\}$, and negative, $\{01 \overline{1} 1\})$, the hexagonal dipyramid $\{h \bar{h} \overline{2 h} l\}$, the pinacoid $\{0001\}$, first-order $\{10 \overline{1} 0\}$ and second-order $\{11 \overline{2} 0\}$ hexagonal prisms, the dihexagonal prism $\{h k i 0\}$, and the ditrigonal scalenohedron $\{h k i l\}$.
Corundum exhibits a wide variety of colors, of which the most sought-after are red rubies, blue sapphires, and orangy pink padparadscha sapphires. These colors result from the substitution of chromophoric trace elements for $\mathrm{Al}$ in the crystal structure (Hughes et al., 2017). When chromium (Cr) replaces $\mathrm{Al}$, the result, depending on the extent of the substitution, is a pink to red color. It is well known that $\mathrm{Cr}$ (along with vanadium, V) is the chromophore responsible for the green color in emerald (see below), but in corundum the distance between the metallic ion and $\mathrm{O}$ is short (1.913 $\AA$ ), and as a consequence the $\mathrm{Cr}^{3+}$ ions show high electrostatic repulsion and absorption features are shifted to higher energies. In the optical absorption spectrum of ruby there are two large absorption bands (figure 4), with transmission windows at $480 \mathrm{~nm}$ (blue visible light) and $610 \mathrm{~nm}$ (red visible light). As the human eye is more sensitive to red than blue light above $610 \mathrm{~nm}$, ruby appears red. Chromium-related red emission under ultravio- 
A
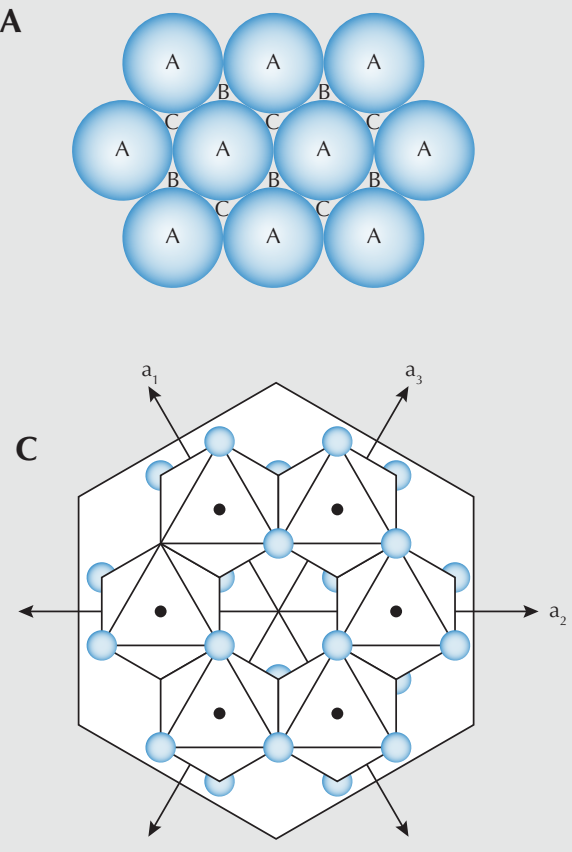

B

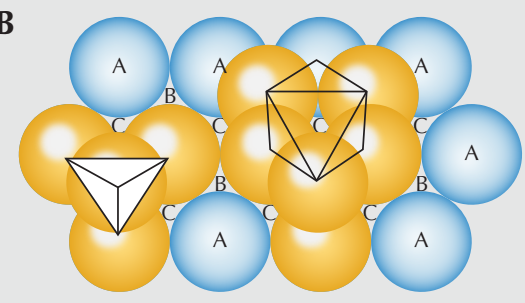

D

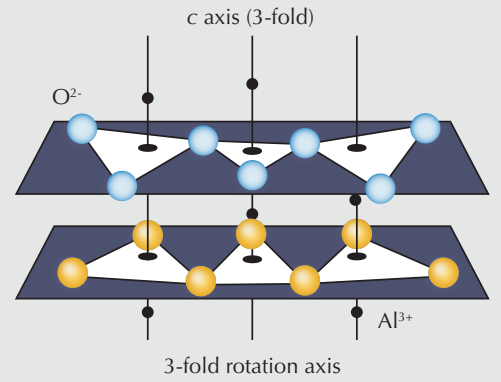

let (UV) light, and sometimes in daylight, is the cause of the fluorescence sometimes observed in (Fe-poor) rubies from certain deposits, including those from Myanmar and Vietnam.

The blue color in corundum requires the interaction of two transition metals, iron (Fe) and titanium (Ti). When $\mathrm{Fe}^{2+}$ and $\mathrm{Ti}^{4+}$ are located at neighboring $\mathrm{Al}$

Figure 3. Crystalline forms of the $\overline{3} 2 / \mathrm{m}$ class of the rhombohedral system (from Giuliani et al., 2014a; after Cesbron et al., 2002). A: Positive rhombohedron \{1011\}. B: Negative rhombohedron \{01111\}. C: Hexagonal dipyramid \{hhil\}. D: Pinacoid \{0001\}. E: First-order hexagonal prism $\{10 \overline{1} 0\}$. F: Second-order hexagonal prism \{1120\}. G: Dihexagonal prism \{hki0\}. H: Ditrigonal scalenohedron \{hkil\}.
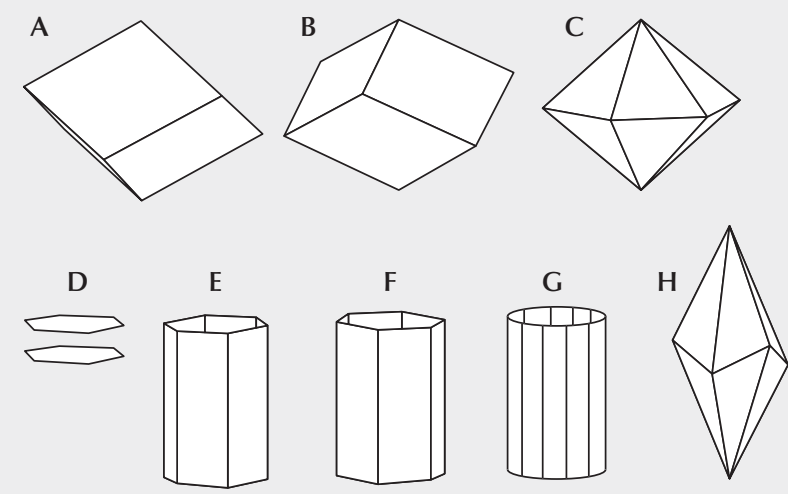

Figure 2. The crystal structure of corundum. A: A single layer of spheres representing $O$ atoms in hexagonal close-packed coordination. In a second layer the spheres would be oriented over the B locations, and a third layer would be over the first (A locations). B: Six O atoms coordinate Al atoms at the $C$ positions, forming an octahedron (the tetrahedrally coordinated site is vacant). Only two out of every three Al sites are occupied in the Al layers. C: The crystal structure of corundum looking down the caxis. D: Perspective view of the crystal structure of corundum. From Giuliani et al. (2014a). sites, an optically induced transfer of an electron (termed "intervalence charge transfer," IVCT) creates an absorption band centered at approximately 580 $\mathrm{nm}$ that is responsible for the blue color (again, see figure 4) (Hughes et al., 2017). This defect assemblage is a very strong absorber and requires very few Fe-Ti pairs (on the order of 10 pairs for $1 \mathrm{~cm}$ of path length) to produce a reasonable saturation of blue color in corundum.

Treatment of corundum generally is focused on improving color. Patches of blue and purplish color in ruby (e.g., from Mong Hsu in Myanmar) are removed by heat treatment in order to create a "purer" red or pink color. The gems are placed in an oxidizing environment, which destroys the $\mathrm{Fe}^{2+}-\mathrm{Ti}^{4+}$ IVCT that may be naturally present and leaves a more desirable pink or red color. The blue color of sapphire is often made deeper by heat treatment using a reducing atmosphere to convert $\mathrm{Fe}^{3+}$ to $\mathrm{Fe}^{2+}$ while also dissolving any $\mathrm{Ti}$ available in mineral inclusions (such as rutile) into the crystal lattice. Once the Ti is dissolved into the lattice, it can pair with the $\mathrm{Fe}^{2+}$, producing the blue color via $\mathrm{Fe}^{2+}-\mathrm{Ti}^{4+}$ IVCT. As discussed by Palke et al. (2019a), pp. 536-579 of this issue, this type of heat treatment can make origin determination more difficult as the natural inclusion scenes that might ordinarily aid in origin determination can be severely altered.

Heat treatment can also serve to improve the clarity of corundum by dissolving inclusions or fusing fractures. This often is done in the presence of a syn- 


\section{UV-VIS ABSORPTION SPECTRA}
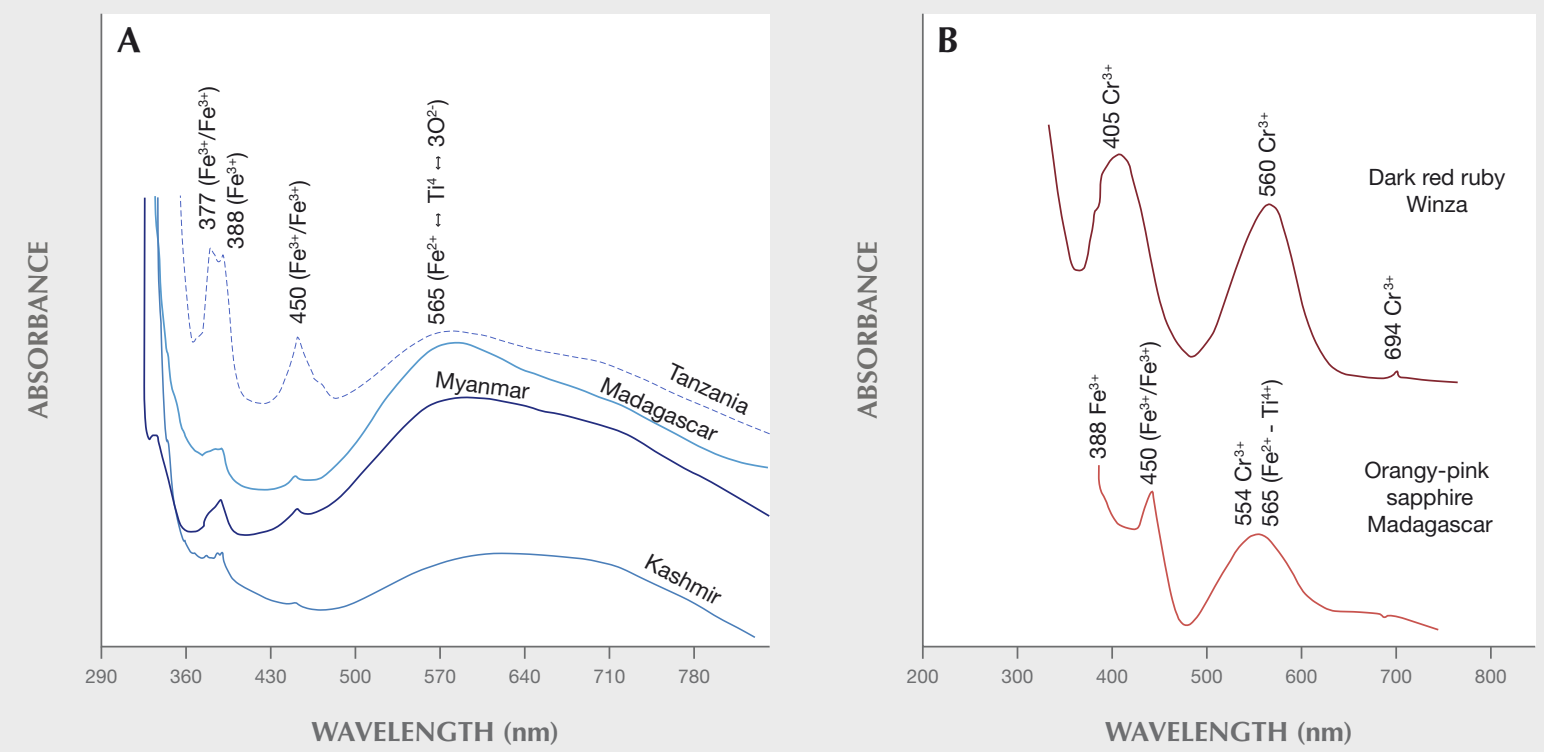

Figure 4. Typical polarized UV-Vis absorption spectra of sapphire and ruby. A: Polarized absorption spectra of four sapphires from different deposits (Notari and Grobon, 2002) showing bands corresponding to chromophores. B: Polarized absorption spectra of Winza ruby (Schwarz et al., 2008) and orangy pink sapphire from Madagascar (Peretti and Günther, 2002). The spectrum of ruby shows the well-known $\mathrm{Cr}^{3+}$ absorption bands at 405-410 and $560 \mathrm{~nm}$, and the Cr "doublet" at $694 \mathrm{~nm}$. The sapphire from Madagascar is close in color to padparadscha.

thetic flux, which facilitates this process at a temperature much lower than the melting point of corundum. Once the fractures are fused together, light can pass through the stone uninterrupted by the lower refractive index of air-filled cracks; this results in significant clarity enhancement and also serves to produce a more durable gemstone. This type of treatment is especially prevalent among rubies, and can sometimes act as a tell-tale sign of origin for certain localities such as Mong Hsu; see Palke et al. (2019b), pp. 580-612 of this issue. Diffusion treatments using Ti and beryllium (Be) are done to improve color but in the case of Ti can even be used to impart stars. Titanium diffusion into Fe-containing corundum in order to produce or enhance a blue color is a lengthy high-temperature process that produces a thin skin of color no more than $0.5 \mathrm{~mm}$ thick. However, Be diffuses easily into the lattice and may penetrate for several millimeters, or through the entirety of small stones. Beryllium diffusion can create many different colors in sapphire, depending upon the nature of trace elements in the gem (see Hughes, 1997; Emmett et al., 2017). GIA never provides origin reports for diffused stones, even if the original corundum was a natural stone.

\section{CHARACTERISTICS OF EMERALD}

Emerald is the green gem variety of the mineral beryl, which has the general formula $\mathrm{Be}_{3} \mathrm{Al}_{2} \mathrm{Si}_{6} \mathrm{O}_{18}$. This uniaxial negative material $\left(\mathrm{n}_{\omega} \approx 1.568-1.602, \mathrm{n}_{\varepsilon}\right.$ $\approx 1.564-1.595$ ) has a specific gravity ranging from approximately 2.6 to 2.9 . Beryl is hexagonal and crystallizes in point group $6 / \mathrm{m} 2 / \mathrm{m} 2 / \mathrm{m}$ and space group $P 6 / \mathrm{m} 2 / \mathrm{c} 2 / \mathrm{c}$. The $\mathrm{Al}$ or $\mathrm{Y}$ site is surrounded by six $\mathrm{O}$ atoms in octahedral coordination, and both the beryllium (Be) and silicon ( $\mathrm{Si}$ ) sites by four $\mathrm{O}$ atoms in tetrahedral coordination (figure 5). The $\mathrm{SiO}_{4}$ tetrahedra share corners to form six-membered rings parallel to (001); stacking of the rings results in large channels parallel to the c crystallographic axis. The diameter of each channel varies from approximately 2.8 to approximately $5.1 \AA$. There are two sites in the channels; these are referred to as the $2 a$ (at $0,0,0.25$, in the wider part) and $2 b$ (at $0,0,0$, in the narrow part) positions.

Emerald crystals typically exhibit a prismatic habit characterized by six first-order $\{10 \overline{1} 0\}$ prismatic faces and two $\{0001\}$ pinacoid faces. Small additional $\{10 \overline{1} 2\}$ and $\{11 \overline{2} 2\}$ faces can also be present.

The color of emerald is due to trace amounts of $\mathrm{Cr}$ and/or $\mathrm{V}$ replacing $\mathrm{Al}$ in the crystal structure. The 

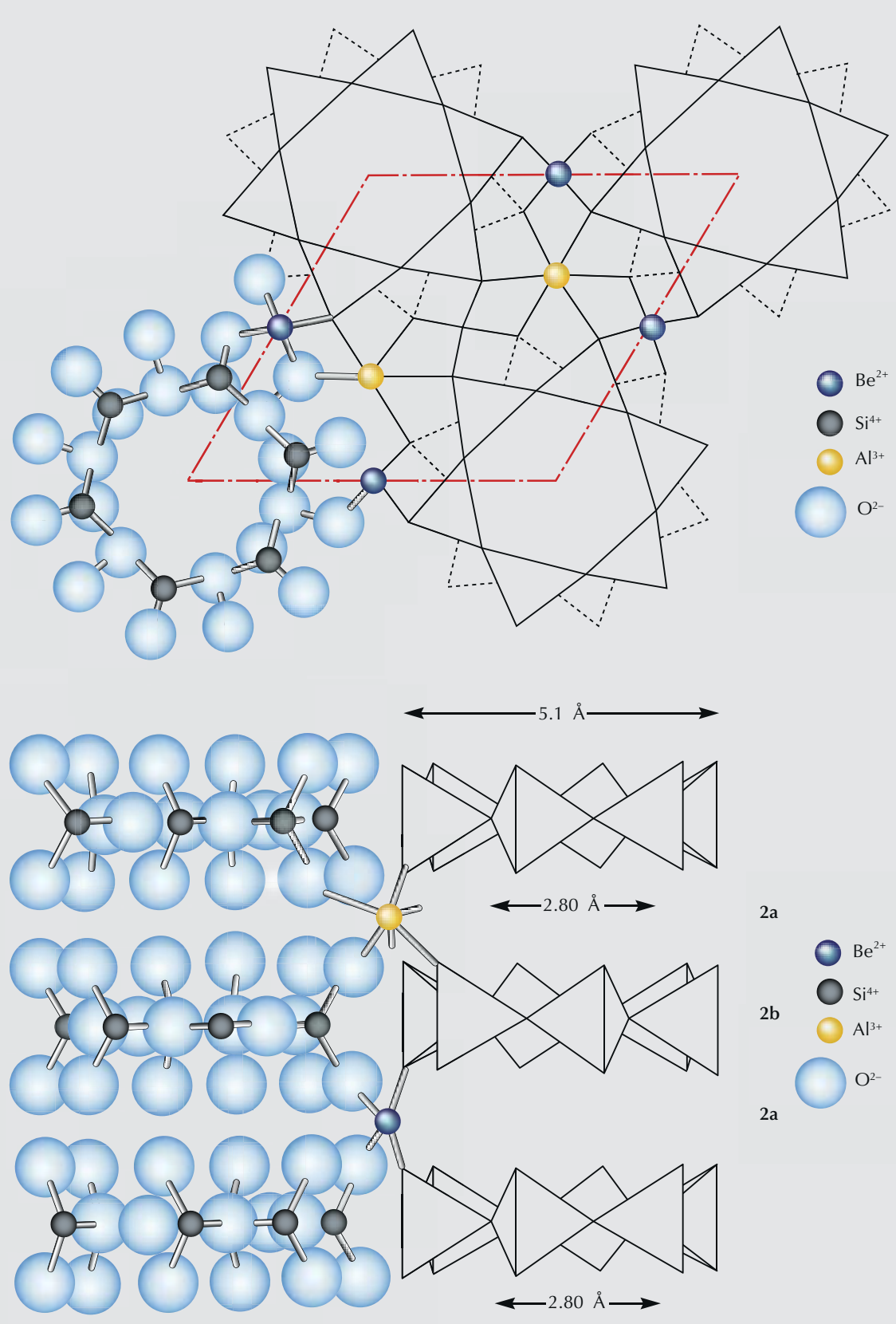

Figure 5. The crystal structure of beryl projected onto (top) (001) and (bottom) (100) showing $\mathrm{SiO}_{4}$ tetrahedra, six-coordinated Al and four-coordinated Be atoms, and levels of the $2 a$ and $2 b$ sites in the channels formed by the hexagonal rings (from Giuliani et al., 2019). presence of $\mathrm{Cr}$ and $\mathrm{V}$ in the beryl structure causes a red fluorescence that enhances the luminosity of the blue-green color, but if $\mathrm{Fe}^{3+}$ is present in the emerald crystal, this effect is suppressed (Nassau, 1983). There has been some debate over the difference between emerald and green beryl (see Conklin, 2002; Schwarz and Schmetzer, 2002).

In most cases the $\mathrm{Cr}_{2} \mathrm{O}_{3}$ content is much higher than that of $\mathrm{V}_{2} \mathrm{O}_{3}$; the main exceptions are for samples from the Lened deposit in Canada, the Davdar and Malipo occurrences in China, the Muzo mine in Colombia, the Mohmand district in Pakistan, and Eidsvoll in Norway.

Most elemental substitutions occur at the $\mathrm{Al}$ site (figure 6; see representative compositions in Groat et al., 2008). Magnesium is the main substituent in most emeralds, but other elements that can substitute for $\mathrm{Al}^{3+}$ include $\mathrm{Sc}^{3+}, \mathrm{Ti}^{4+}, \mathrm{V}^{3+}, \mathrm{Cr}^{3+}, \mathrm{Mn}^{2+}, \mathrm{Fe}^{2+, 3+}$, $\mathrm{Co}^{2+}, \mathrm{Ni}^{2+}, \mathrm{La}^{3+}$, and $\mathrm{Ce}^{3+}$. Lithium $\left(\mathrm{Li}^{+}\right)$can also substitute for beryllium at the Be site. To achieve charge 


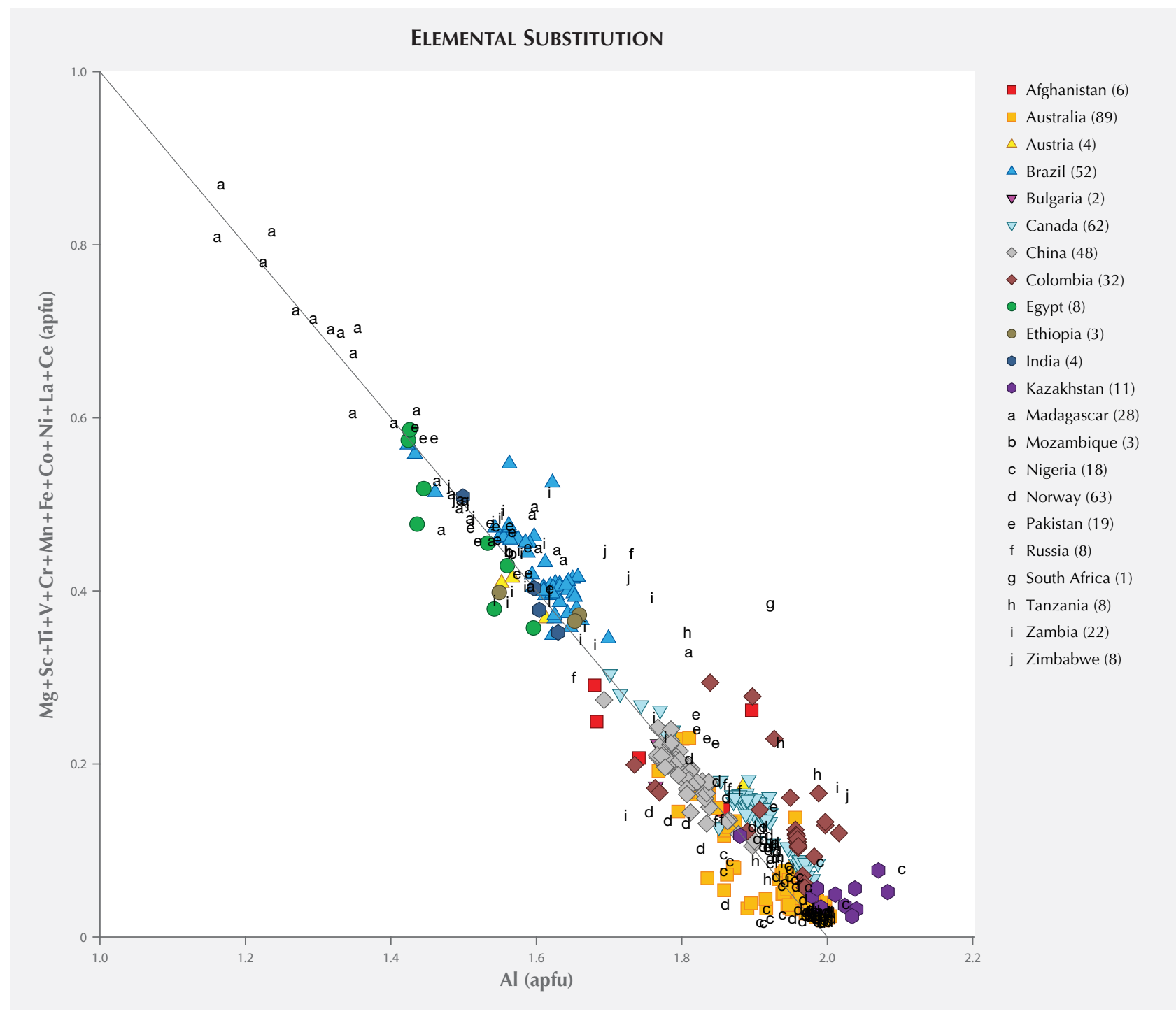

Figure 6. Al versus the sum of other Y-site cations, in atoms per formula unit, for 499 emerald analyses from the literature. The number of analyses per country is given in parentheses in the legend. Sources of data: Kovaloff (1928); Zambonini and Caglioti (1928); Leitmeier (1937); Otero Muñoz and Barriga Villalba (1948); Simpson (1948); Gübelin (1958); Vlasov and Kutakova (1960); Martin (1962); Petrusenko et al. (1966); Beus and Mineev (1972); Hickman (1972); Garstone (1981); Hänni and Klein (1982); Graziani et al. (1983); Kozlowski et al. (1988); Hammarstrom (1989); Ottaway (1991); Schwarz (1991); Artioli et al. (1993); Schwarz et al. (1996); Giuliani et al. (1997b); Abdalla and Mohamed (1999); Gavrilenko and Pérez (1999) (Kazakhstan values are averages of 11 analyses); Alexandrov et al. (2001) (average of 10 analyses), Groat et al. (2002); Marshall et al. (2004) (two averages of five analyses each), Vapnik et al. (2005, 2006); Zwaan et al. (2005); Gavrilenko et al. (2006); Zwaan et al. (2006) (average of 55 analyses); Rondeau et al. (2008); Andrianjakavah et al. (2009); Brand et al. (2009); Loughrey et al. (2012); Marshall et al. (2012); Zwaan et al. (2012); Loughrey et al. (2013); Marshall et al. (2016) (average of 37 analyses); Lake et al. (2017) (average of 88 analyses); Aurisicchio et al. (2018); Santiago et al. (2018) (average of approximately 130 analyses); Giuliani et al. (2019).

balance, the substitution of divalent cations for $\mathrm{Al}$ is coupled with the substitution of a monovalent cation $\left(\mathrm{Na}^{+}, \mathrm{Cs}^{+}, \mathrm{Rb}^{+}\right.$, and $\left.\mathrm{K}^{+}\right)$for a vacancy at a $2 a$ or $2 b$ site in the channel (figure 7). Artioli et al. (1993) suggested that, in alkali- and water-rich beryls, $\mathrm{H}_{2} \mathrm{O}$ molecules and the larger alkali atoms $(\mathrm{Cs}, \mathrm{Rb}, \mathrm{K})$ occupy the $2 a$ sites and $\mathrm{Na}$ atoms occupy the smaller $2 b$ positions, while in alkali- and water-poor beryl, both $\mathrm{Na}$ atoms and $\mathrm{H}_{2} \mathrm{O}$ molecules occur at the $2 a$ site and the $2 b$ site is empty. 
While some gems, such as aquamarine in pegmatites, crystallize in relatively stable environments that allow for continuous growth without strong perturbations, emeralds are formed in geologic environments characterized by abrupt changes and mechanical stress (Schwarz, 2015). This results in smaller crystals with considerable internal defects, such as inclusions and fractures. Therefore, the most common treatment for emeralds is clarity enhancement, which is accomplished by injecting a material (typically an oil or resin) of similar refractive index into the fractures. This is typically done under vacuum in order to completely fill the cracks with a filler of matching refractive index, lowering the relief of the once air-filled cracks. The vast majority of emeralds on the gem market are treated in this manner to varying degrees.

\section{ANALYTICAL METHODS USED FOR ORIGIN DETERMINATION}

Corundum and emerald and their inclusions are identified and characterized using a variety of meth- ods, many of which (especially when used in combination) provide data that can also be used for origin determination. Various methods are used to identify basic physical properties, inclusions, spectroscopic characteristics, trace element chemistry, and isotopic chemistry.

Inclusion Identification. The positive identification of inclusions contained within a gemstone can hold the key to its origin. At GIA, combining this with knowledge of the trace elements present is often enough to make an origin determination. Establishing the identity of an inclusion traditionally has been done visually with reference to known inclusions. However, Raman spectroscopy is now routinely used to positively identify mineral inclusions by reference to established spectroscopic databases.

Microscopy. Optical microscopy can be used to characterize optical properties (such as refractive indices and birefringence), growth features, solid inclusions (on the basis of color and morphology), and fluid in-

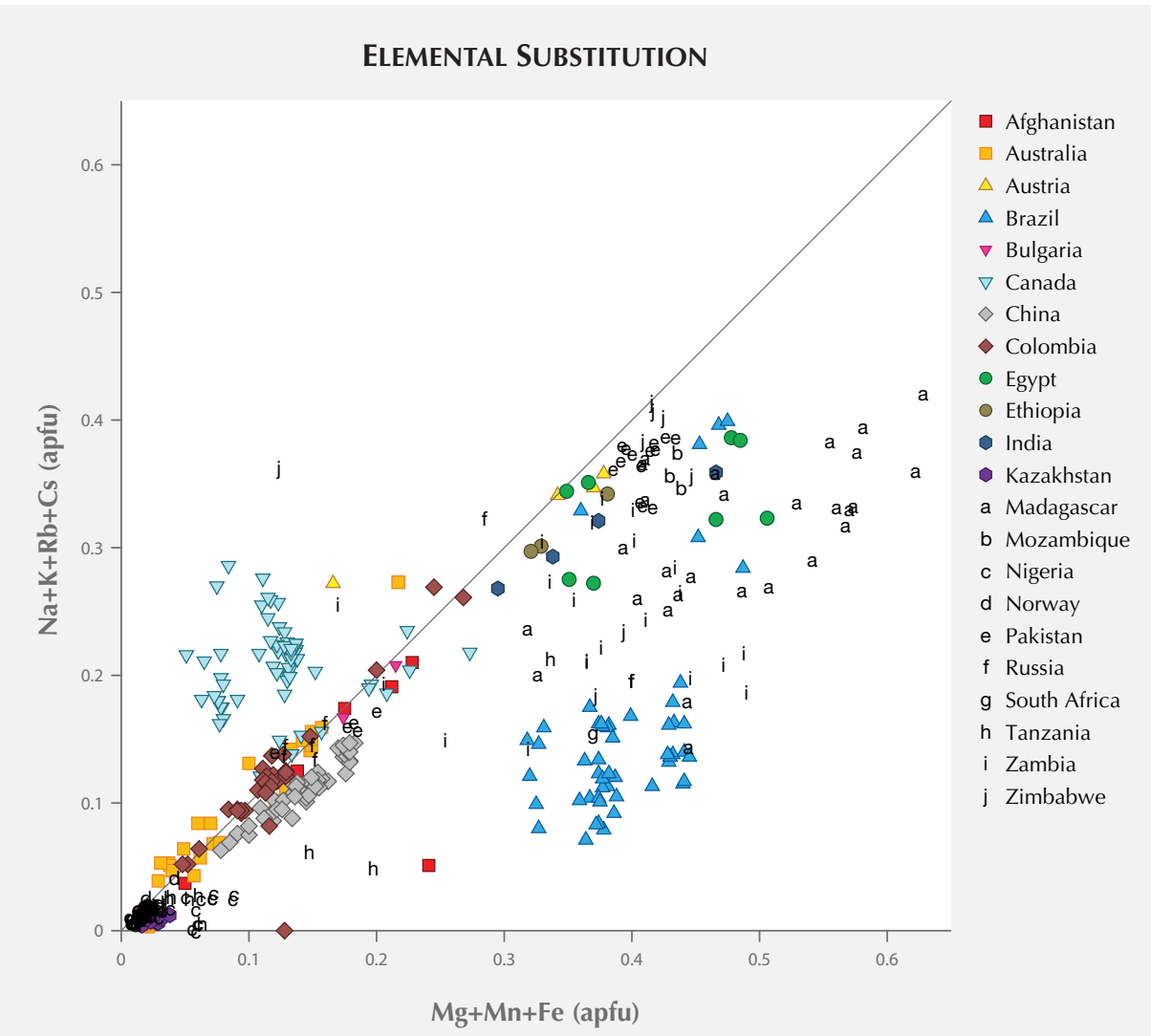

Figure 7. $\mathrm{Mg}+\mathrm{Mn}+\mathrm{Fe}$ versus monovalent channel-site cations, in atoms per formula unit, for analyses from the literature. Sources of data are the same as in figure 6. Points above the 1:1 line suggest Li substitution in the crystal structure; points below the line suggest that some of the Fe is present as $\mathrm{Fe}^{3+}$. 
clusions (shape and ratios of solid:liquid:vapor), if present, as the finest-quality gems will by definition exhibit few inclusions of any kind. Observation of a stone's inclusion characteristics provides some of the most important information available to the gemologist when making geographic origin calls. The most commonly used tool in the gemological lab is a binocular microscope equipped with darkfield illumination. This illumination environment provides higher contrast of a stone's inclusions by causing light to enter the stone from a wide range of angles rather than from below the stone only. This is often supplemented by the use of a strong fiber-optic light, especially when used to highlight rutile silk in sapphires and rubies. Solid and fluid inclusions in gemstones are often identified by observing their morphology, color, luster, and other properties and comparing against possible options for a given host mineral based on an understanding of their geological origins. After inclusions with a certain appearance have been confirmed with Raman spectroscopy, their identity can often be assumed when observed later by comparison.

Microscopy is also the first step in identifying heat-treated corundum and synthetics that have been erroneously submitted to the lab for origin reports. Stones that have been heated only (i.e., without Be or Ti diffusion) can be issued origin reports. However, determining origin can be more difficult for heated stones, especially metamorphic blue sapphires; see Palke et al. (2019a), pp. 536-579 of this issue.

Raman Spectroscopy. When a laser is aimed at a material, almost all of the reflected laser light undergoes Rayleigh scattering (and hence is elastically scattered light with the same wavelength as the incident laser light), but a very small percentage of the reflected laser light is at a different wavelength because of inelastic (Raman) scattering of the laser light by molecular vibrations (Zaszczak, 2013). Most materials exhibit a characteristic Raman spectrum that can be used for identification. Reliable reference spectra are available from sources such as the RRUFF database (rruff.info). Raman spectroscopy allows subsurface analyses of many types of solid inclusions and can also be used to identify solids and molecular phases in fluid inclusions.

Spectroscopy. By looking at the spectroscopic signatures of gemstones in light ranging from the ultraviolet through the visible and into the infrared, we can oftentimes determine some very basic information re- lated to the geological formation or treatment history. These spectroscopic measurements are quick, nondestructive, and provide invaluable information to help guide our next steps in origin determination.

Ultraviolet/Visible/Near-Infrared (UV-Vis-NIR) Spectroscopy. High-quality absorption spectroscopy is a valuable tool to understand the chemical properties of a gemstone and to identify the color-causing agents in a material, which can be useful in origin determination. This technique relies on passing white light through a stone and measuring how much light gets absorbed by (or transmitted through) the stone from the ultraviolet to the near-infrared. For most colored stones, the transition metals and other defects that can cause color can also have absorption that extends into the ultraviolet and near-infrared. For origin determination, it can be important to identify certain chromophores, such as copper in tourmaline, in order to confidently apply the "Paraíba-type" tourmaline varietal name.

For other materials, the color-causing agents are not so important for origin determination, but certain absorption features can be useful to narrow down the range of possibilities; see Palke et al. $(2019 \mathrm{a}, \mathrm{b})$, pp. 536-579 and pp. 580-612 of this issue; Saeseaw et al. (2019), pp. 614-646 of this issue. Specifically, emeralds can be separated into tectonic-metamorphic-related and tectonic-magmatic-related groups based on the intensity of iron-related bands, and blue sapphires can be separated into metamorphic and basalt-related groups based on the intensity and/or absence of an absorption band at $880 \mathrm{~nm}$ (Giuliani and Groat, 2019, pp. 464-489 of this issue).

Infrared Spectroscopy (IR). Today this almost always refers to Fourier-transform infrared spectroscopy (FTIR). This form of vibrational spectroscopy is based on the reflectance, transmittance, or absorbance of infrared light by a material. This technique relies on the fact that a sample absorbs different amounts of light at distinct frequencies that correspond to the vibrational frequencies of the bonds in the sample. However, transmission IR spectroscopy is typically used to study discrete molecules within a crystal structure, such as $\mathrm{H}_{2} \mathrm{O}$ at the channel sites in emerald, and to observe hydroxyl bands and other features in corundum that can be useful for detection of heat treatment. Synthetic alexandrite and emerald that have been unwittingly submitted for an origin report can also often be identified by observation of specific 
fingerprints in the hydroxyl-stretching region of an FTIR spectrum. Infrared spectroscopy can also be used to identify solids and molecular phases (such as $\mathrm{H}_{2} \mathrm{O}, \mathrm{CO}_{2}$, and $\left.\mathrm{CH}_{4}\right)$ in fluid inclusions. Additionally, Saeseaw et al. (2014) explored the potential of using FTIR to identify different groups of emeralds based on the structure around water molecules in the beryl channel, which might have potential in providing an additional discriminant variable for origin determination. At the moment, however, the use of this technique is still in the exploratory stage.

Trace Element Chemistry. Being able to detect the presence or absence and relative quantities of a variety of trace elements in ruby, sapphire, emerald, tourmaline, alexandrite, and spinel can sometimes quickly rule in or rule out particular origins. Determining trace element chemistry efficiently with high levels of accuracy to very low concentrations in a nondestructive manner is a considerable challenge. An overview of four different methods used by the geological and gemological communities is presented, outlining the advantages and limitations of each.

Energy-Dispersive X-Ray Fluorescence Spectroscopy (EDXRF). This technique relies on the interaction of $\mathrm{X}$-rays and a sample and takes advantage of the fact that each element has a unique atomic structure, which results in a unique set of peaks on an emission spectrum. In the laboratory, this method requires no real sample preparation, and it is quick and nondestructive. The excitation source may be a beam of electrons (as in the scanning electron microscope) or an X-ray source (as in handheld X-ray fluorescence spectrometers). This technique is used to determine the elements present in a sample, and can be used to estimate their relative abundances; however, due to factors such as X-ray absorption and overlapping Xray emission peaks, accurate estimation of the sample composition requires the application of quantitative corrections (sometimes referred to as matrix corrections). Beyond limits in accuracy, some key lighter trace elements (those lighter than sodium) cannot be detected. When applied with care, however, EDXRF can produce reliable results, although its precision and high detection limits cannot match more advanced techniques such as LA-ICP-MS (see below).

Electron Probe Micro-Analyzer (EPMA). This technique is most often used to quantify major element compositions of minerals and is accurate to the parts per million level. In the electron microprobe, the sample is attached to a stage (movable in $\mathrm{x}, \mathrm{y}$, and $\mathrm{z}$ axes) at one end of a column with a filament at the opposite end. Air is removed from the column until a high vacuum is achieved and then high voltage is applied to the filament, which gives off electrons. Electromagnets in the column shape the electrons into a narrow (generally 1-5 micron) beam that is directed onto the sample. The elements making up the sample emit characteristic X-rays, which are diffracted and detected by a wavelength-dispersive spectrometer. The intensity of the X-ray energy given off by an element is compared to that emitted by a standard sample of known composition (a calibration standard), and then matrix corrections are applied to this intensity ratio to yield concentrations.

Electron microprobe compositions are usually given in terms of weight percent oxides, because in most minerals $\mathrm{O}$ is by far the most abundant element. Although it is possible to measure oxygen, there is less error involved in measuring the cations and allocating the $\mathrm{O}$ for charge balance.

Much of the early research on origin determination was carried out using electron microprobe analyses (e.g., Giuliani et al. 2014b). The technique is not destructive per se, but analyzing gems requires special sample holders that generally must be customfabricated. As such, it is not a standard gemological laboratory instrument and is more suited for analyzing geological samples collected in the field.

Analyses of light elements are often less accurate (10-20 rel.\% for Li and Be; R. Škoda, pers. comm., 2019) because of their low X-ray yield (resulting in low count rates and low peak-to-background ratios) due to X-ray absorption in the specimen, the analyzer crystal, and the detector window. This is why most published analyses of beryl are renormalized with an assumed three Be atoms per formula unit.

Electron microprobe analyses can be used to narrow down the origin of emerald - for example, to determine whether $\mathrm{Cr}$ or $\mathrm{V}$ is the principal chromophore. It is less useful for corundum, where the trace elements generally occur in much lower concentrations and interferences (peak overlap) among many of the transition elements ( $\mathrm{Ti}, \mathrm{V}$, and $\mathrm{Cr})$ makes them difficult to measure.

Electron microprobe instruments are very expensive to purchase, maintain, and operate, which is why they are rarely found outside the university environment. For trace element determinations, this method has largely been supplanted by the following 


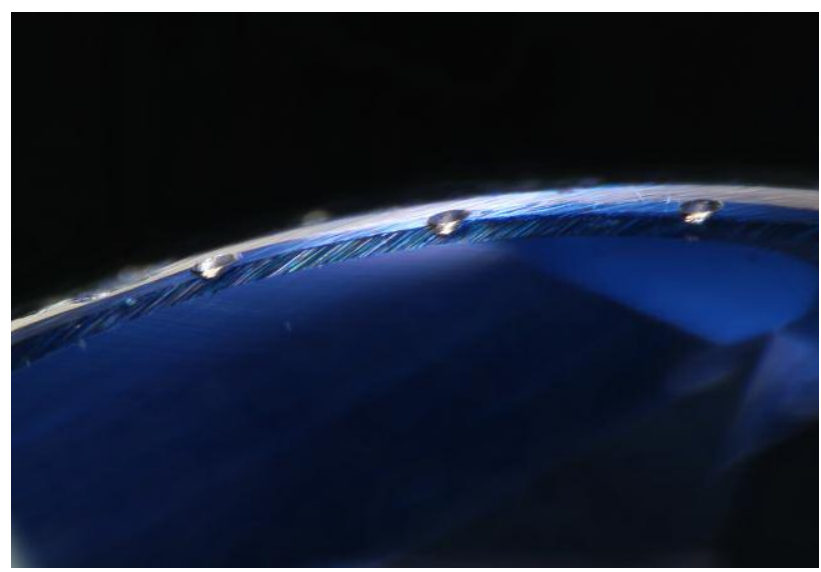

Figure 8. Typical laser ablation spots placed on the girdle of a synthetic sapphire. The field of view is 1.58 $\mathrm{mm}$ and the pits are 60 microns in diameter. Photo by Jonathan Muyal.

technique, which is faster and benefits from better detection limits.

Laser Ablation-Inductively Coupled Plasma-Mass Spectrometry (LA-ICP-MS). With the introduction of sapphire color enhancement via beryllium diffusion treatment around 2002 (Emmett et al., 2003), the gemological community needed an analytical method capable of detecting Be, as EDXRF and EPMA cannot. LA-ICP-MS was adopted shortly thereafter to meet this need and proved to be highly useful beyond just detecting Be diffusion treatment in sapphire. This method is fast, detects elements from Be to $\mathrm{U}$ at ppm to ppb levels simultaneously, and the sample chambers available allow for analyzing stones in virtually any form, including mounted in jewelry (e.g., Abduriyim and Kitawaki, 2006). In this technique, an ultraviolet laser beam (such as 213 and $193 \mathrm{~nm}$ ) is used to generate aerosols from the sample surface. The ablated material is then transported into the plasma, where it is ionized. The ions generated in the plasma torch are then introduced to a mass analyzer for elemental and isotopic analysis. However, mass interferences must be accounted for; when the sample is ablated, species with masses similar to elements of interest can occur, generating falsely elevated levels. To have enough signal to quantify trace elements with small ablation spots, gemological labs typically employ quadrupole mass spectrometers with modest massresolving powers (MRP) of around 300. The MRP necessary to separate a species of interest from a close-in-mass interference is simply the ratio of the mass of the species of interest divided by the differ- ence between that mass and the close-in-mass interference of concern.

To quantify the various trace elements in a given gem material, calibration standards must be used. There are many traditional calibration standards commercially available, such as those manufactured by the National Institutes of Standards (NIST) or the United States Geological Survey (USGS). At GIA, a desire for enhanced trace element accuracy for ruby and sapphire led to the development of its own corundum calibration standards for LA-ICP-MS (see box A).

While LA-ICP-MS is considered a semi-destructive technique in that the process leaves ablation pits, the generally small size chosen for the pits $\mid \sim 50$ $\mu \mathrm{m}$ ) means that they are impossible to see without magnification (figure 8 shows typical laser ablation spots placed on the girdle of a synthetic sapphire). As each mineral species interacts differently with the UV laser light, evaluating the ablation pits generated with different laser conditions is recommended.

Secondary Ion Mass Spectrometry (SIMS). Because LA-ICP-MS is limited by the inability to separate some close-in-mass interferences while still being able to detect to the ppm and sub-ppm levels, SIMS (figure 9) can be an attractive option. When extreme sensitivity and high mass resolution are required, SIMS is potentially the best choice. Its sensitivity for all isotopes to the ppm and ppb level is unequaled while still being able to employ MRPs of 3000 to 6000. This technique involves sputtering the surface of a sample with a primary beam of ions to generate, collect, and analyze secondary ions. As the relative signal generated varies not only by species but also by what matrix a species is in, relative sensitivity factors (RSF) need to be developed for every combination of trace element and matrix. These RSF values are derived from depth profiling primarily ion implant standards for this conversion of relative signal to concentration. The RSF values are also impacted by the choice of primary ion beam and the analytical conditions (beam polarity, current, and potential). The matrix-matched corundum standards developed by GIA (detailed in box A) were all calibrated using SIMS. In all, RSF factors were developed for 18 trace elements in corundum $(\mathrm{Be}, \mathrm{Mg}$, Si, $\mathrm{Ca}, \mathrm{Sc}, \mathrm{Ti}, \mathrm{V}, \mathrm{Cr}$, $\mathrm{Mn}, \mathrm{Fe}, \mathrm{Co}, \mathrm{Ni}, \mathrm{Cu}, \mathrm{Zn}, \mathrm{Ga}, \mathrm{Ge}, \mathrm{Zr}$, and $\mathrm{Pb}$ ) to not only cover those trace elements regularly characterized for origin determination but also to further research on trace elements we expect could be present based on size and valency. However, gemological lab- 


\section{Box A: Matrix-Matched Corundum Standards at GIA}

The onset of beryllium diffusion treatment of sapphire signaled a need for better quantitative analysis capabilities in gemological laboratories (Emmett et al., 2003). Energy-dispersive X-ray fluorescence (EDXRF) - the traditional instrumentation used to detect trace elements in gems-was completely blind to this critical trace element being artificially introduced into natural sapphire. To address this, GIA and other gem laboratories adopted laser ablation-inductively coupled plasmamass spectrometry (LA-ICP-MS).

At GIA, corundum (ruby and sapphire) accounts for most of the gemstones submitted for origin services. Only a small handful of trace elements are typically present $(\mathrm{Mg}, \mathrm{Ti}, \mathrm{V}, \mathrm{Cr}, \mathrm{Fe}$, and $\mathrm{Ga})$, and these are usually at very low concentrations (generally less than 100 ppma and often less than 10 ppma), making the chemical analyses extremely difficult. Additionally, much research at GIA involving the color origin of corundum also requires trace element quantification of chromophore chemistry with atomic-level accuracy. For this reason, the GIA laboratory has focused on producing the highest-quality and most accurate trace element analyses possible for corundum and ensuring that these results are consistent across its five global identification laboratories.

For more than a decade, GIA has invested in creating its own matrix-matched standards for ruby and sapphire. In 2006, the first set of corundum matrix-matched standards was introduced into its laboratories (Wang et al., 2006). For a decade, these standards were used to quantify $\mathrm{Be}, \mathrm{Mg}$, Ti, V, Cr, Fe, and Ga in corundum. In 2016, an updated set was developed to offer multiple and more optimal levels of some trace elements, and to reduce the number of individual standards (Stone-Sundberg et al., 2017). Additionally, a high-purity synthetic sapphire "blank" was introduced, allowing users to correct for mass interferences from the matrix itself. Currently, GIA is releasing a third set of matrix-matched corundum standards for both internal use and outside distribution (figure A-1). This third generation of corundum standards adds a calibrated value for $\mathrm{Ni}$.

In comparing results from calibrating LA-ICP-MS with NIST SRM 610 and 612 against our corundum standards, we have found that using NIST SRM 610 and 612 can result in underreporting the levels of $\mathrm{Be}, \mathrm{Ti}, \mathrm{V}, \mathrm{Fe}$, $\mathrm{Ni}$, and $\mathrm{Ga}$ (the levels of $\mathrm{Mg}$ are slightly overreported using NIST SRM 610 and 612, and Cr appears to be reasonably accurate within error). The generation of suppressed trace element concentrations with NIST standards can result from differences in the way the laser interacts with the two different matrices.
This lengthy and expensive undertaking to create single-crystal matrix-matched standards for ruby and sapphire required working with several highly specialized vendors. These included synthetic Czochralski crystal growers to produce the specifically targeted trace element contents of the crystals, secondary ion mass spectrometry (SIMS) laboratories to generate corundumspecific relative sensitivity factors for the elements of interest and calibrate the individual standards, ion implanters to create the secondary standards for SIMS, and laboratories with Rutherford backscattering spectrometry (RBS) capabilities to validate our ion implants prior to calibration efforts. This process could be replicated for other matrices if desired in the future.

Figure A-1. GIA's corundum standards set for matrixmatched LA-ICP-MS measurement of trace elements in ruby and sapphire. Each corundum standard is laser inscribed. The number 16-0524-06 corresponds to the high-purity corundum blank, 07-0687-14 and 02-128729 are Czochralski-grown doped synthetic corundum, and Y-1212 is a Yogo sapphire wafer used for Fe and Ni measurements.

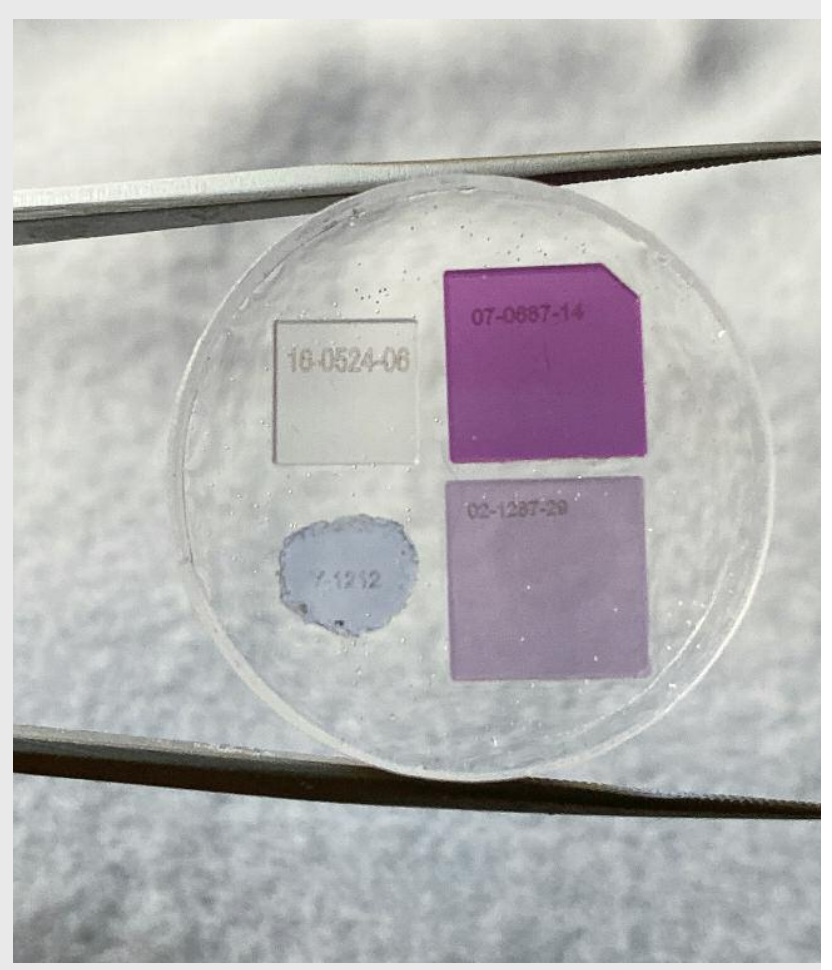




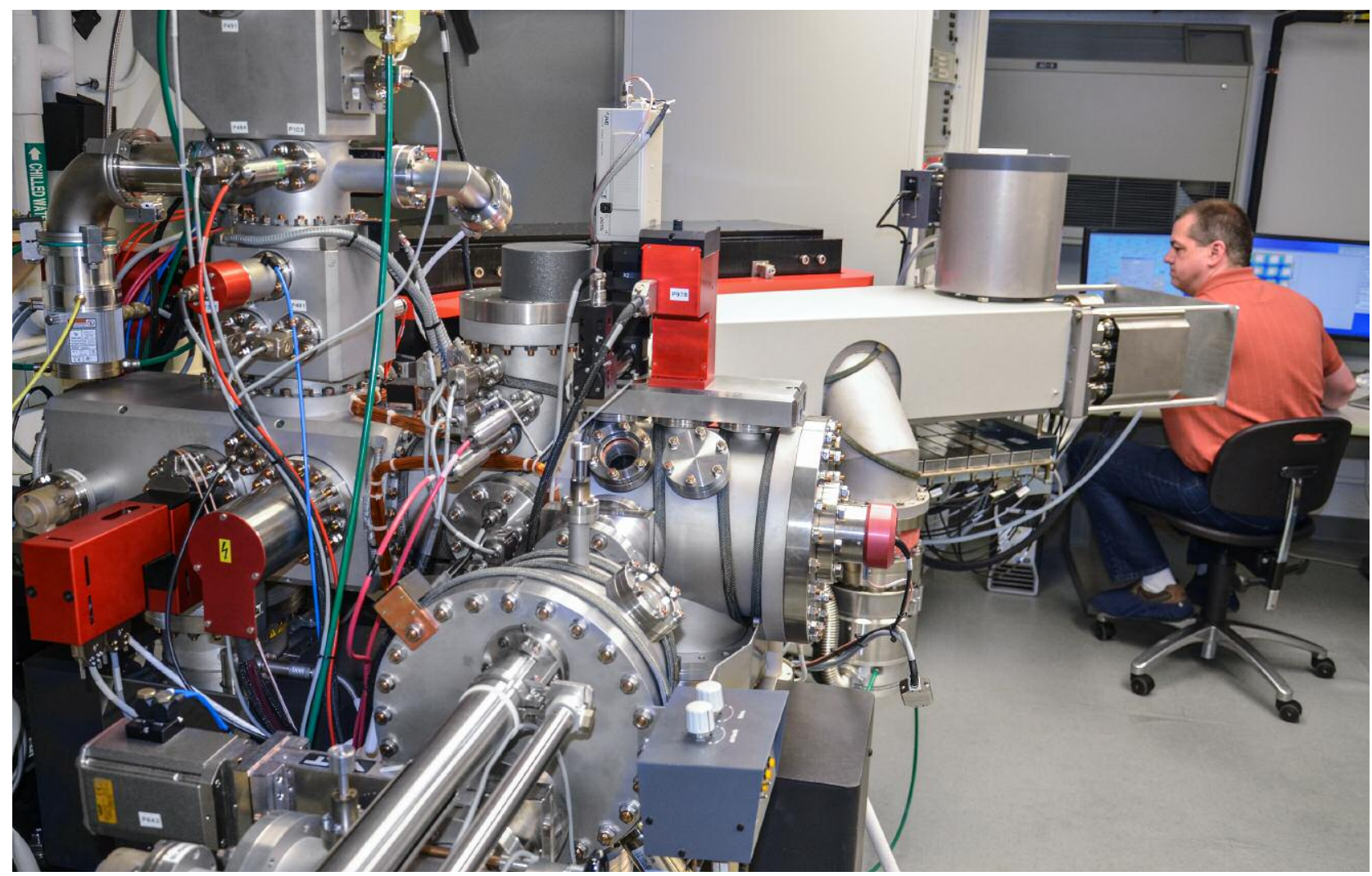

Figure 9. A secondary ion mass spectrometry (SIMS) instrument at the Carnegie Institution for Science in Washington, DC. Photo by Duncan Pay.

oratories will not be adopting SIMS equipment anytime soon, as this instrumentation is extremely expensive, requires highly specialized technicians and facilities to run it, is slow, and has rigid sample requirements that make it difficult to run most of the material submitted to gem labs today. However, it is a very useful tool presently for detecting trace and very trace elements that are difficult or impossible to accurately measure with LA-ICP-MS due to mass interferences. For example, we are actively exploring the wide range of $\mathrm{Si}$ in ruby and sapphire (and what it can tell us about origin), which currently can only be accurately quantified to the ppma level with SIMS.

Isotopic Studies. Presently, gemological laboratories do not incorporate isotopic analysis into their origin determination, but in the future it could have a place. Stable isotope geochemistry deals with isotopic variations that arise from isotope exchange reactions or mass-dependent fractionations that take place during the physical and chemical processes responsible for the formation of gems. The magnitude and temperature dependence of isotopic fractionation factors between minerals and fluids permit reconstitution of the geological history of gems in terms of source of the element and origin of the fluids (Fallick et al., 1985). Generally, stable isotopes are measured by mass spectrometry (including LA-ICP-MS and SIMS). Natural variations in isotopic ratios for gem minerals have been reported for only five light elements, namely carbon $(\mathrm{C})$ and nitrogen $(\mathrm{N})$ for diamond; $\mathrm{O}$ for oxides; hydrogen $(\mathrm{H}), \mathrm{O}$, and boron $(\mathrm{B})$ for silicates; and heavier elements such as copper $(\mathrm{Cu})$ for turquoise and $\mathrm{S}$ for lapis lazuli (Giuliani and Fallick, 2018). The stable isotope signatures of gems such as emerald, ruby, sapphire, agates, turquoise, and garnet shed light on the nature of the fluids, the source of the elements responsible for their formation, and in some cases their geographic origin (Giuliani et al., 2000a,b).

Oxygen is a dominant element, and the two main stable isotopes ${ }^{18} \mathrm{O}$ and ${ }^{16} \mathrm{O}$ are used for geological and geographical determinations. The ${ }^{18} \mathrm{O} /{ }^{16} \mathrm{O}$ ratio is $2.0052 \times 10^{-3}$ - that is, for one atom of ${ }^{18} \mathrm{O}$ there are on average 500 atoms of ${ }^{16} \mathrm{O}$. This ratio varies as a function of the geological context and the physical and chemical conditions that prevailed during gem formation, namely: (1) the source of O-i.e., the Oisotopic composition of the gem host rock and/or 


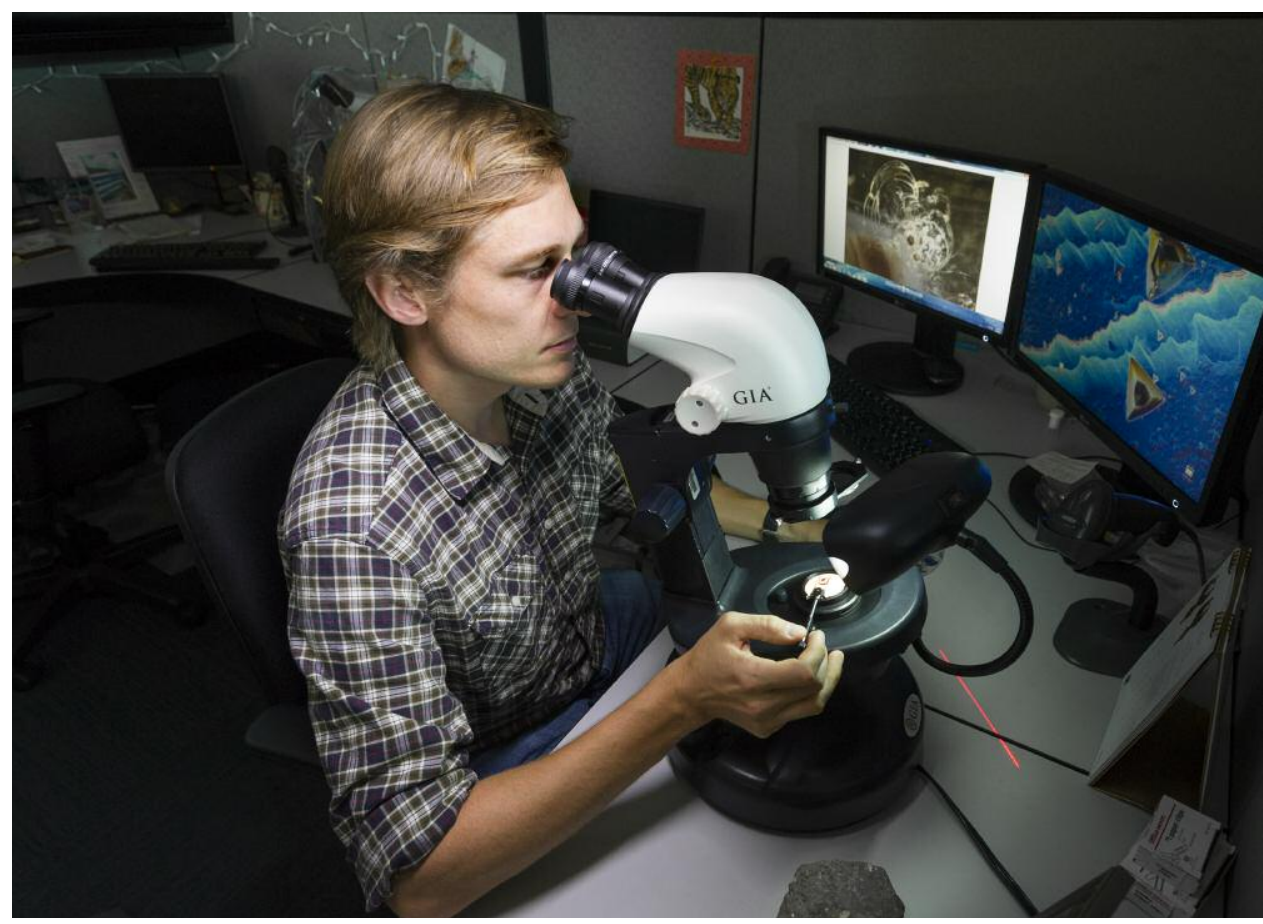

Figure 10. Careful microscopic observations of a stone's inclusion characteristics are an integral part of the origin determination process. Photo by Kevin Schumacher.

parental fluid; (2) the temperature of its formation; and (3) the intensity of the fluid-rock interaction in an open or closed geological system. The concentration of an isotope is usually given as a ratio-e.g., $\delta^{18} \mathrm{O}$, in per mil, where the standard has a known isotopic composition. Data are reported in the conventional $\delta^{18} \mathrm{O}$ notation as per mil (\%o) relative to the Vienna Standard Mean Ocean Water (VSMOW), with $\delta^{18} \mathrm{O}=\left(\left\{\left[{ }^{18} \mathrm{O} /{ }^{16} \mathrm{O}_{\text {sample }}\right] /\left[{ }^{18} \mathrm{O} /{ }^{16} \mathrm{O}_{\text {standard }}\right]\right\}-1\right) \times 10^{3}$. Isotopes have the same number of protons but different numbers of neutrons.

\section{ANALYTICAL WORKFLOW FOR ORIGIN DETERMINATION AT GIA}

When a gemstone is submitted to the GIA lab for an origin report, there is a workflow that routes the stone through a series of tests in order to collect sufficient data to establish the information contained on the report. The stone could be red, blue, or green; round brilliant, a cabochon, or square step cut — every origin call in the lab starts with identification, utilizing standard gemological testing, such as refractive index and specific gravity measurements to determine what the gem material is. The refractive index is measured on a standard gemological refractometer and specific gravity on a high-precision, well-calibrated scale that can measure a stone's weight suspended in water or on its own. Once the gem material is confirmed, further advanced testing may be used if an origin report is requested: Ruby, sapphire, emerald, alexandrite, Paraíba-type tourmaline, and red spinel are currently eligible for this service. Each material requires a specific decision making process when making a geographic origin determination.

Once a stone has been identified as one of the materials for which GIA offers origin reports and the service is requested, the origin determination process begins. In most cases, this starts with careful observations of the stone's inclusions using a standard gemological microscope (figure 10) with a variety of lighting conditions including darkfield, brightfield, fiber-optic illumination, and cross-polarized illumination. For some materials (especially blue sapphires, rubies, and emeralds) microscopic evidence constitutes much of the decision making process for an origin report. Microscopic observation also allows the gemologist to identify many synthetic stones that have unknowingly been submitted for origin reports. If needed, confocal Raman spectroscopy can be used to positively identify mineral inclusions in a stone (again, see figure 1). In order to correlate a stone's inclusion scene to a geographic origin, GIA gemologists have access to an extensive colored stone reference database. Over more than a decade, data from stones of known provenance collected through GIA's field gemology program (see Vertriest et al., 2019, pp. 490511 of this issue) in the form of photomicrographs, trace element chemistry, and spectra have been entered in this database. 


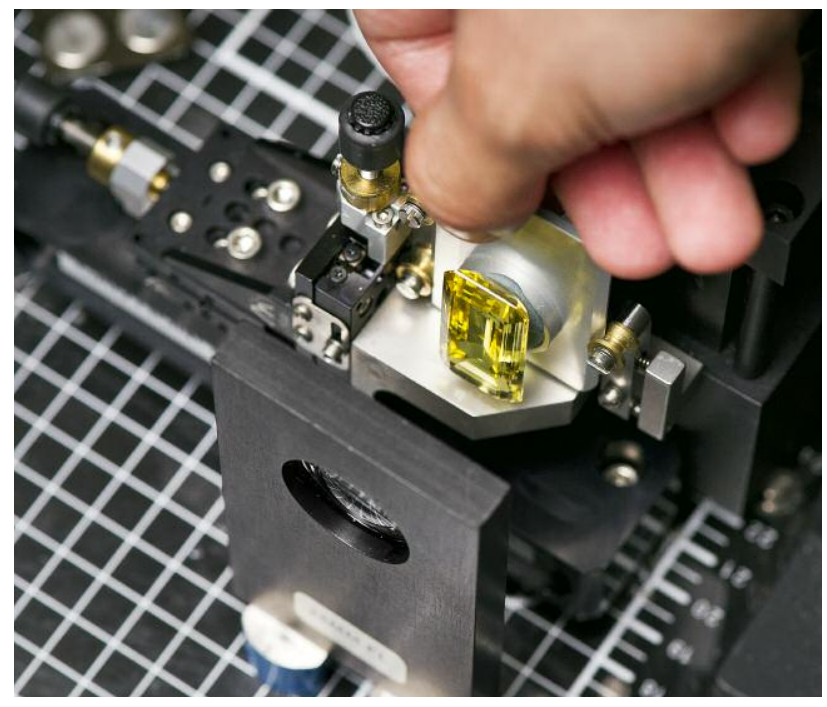

Figure 11. UV-Vis spectroscopy can provide additional evidence for some stones to narrow down the possible choices for a geographic origin determination. Photo by Kevin Schumacher.

Sometimes an inclusion scene can provide convincing evidence of a stone's geographic origin. Sometimes the gemologist is not so lucky and inclusions are ambiguous or absent in stones that are particularly clean. Regardless, microscopic evidence must be backed up with additional advanced testing. Emeralds and blue sapphires require UV-Vis-NIR spectroscopy (figure 11), where the presence or absence of certain absorption bands allows the separation of tectonic-metamorphic-related versus tectonic-magmatic-related emeralds, or metamorphic versus basalt-related blue sapphires (Saeseaw et al., 2019, pp. 614-646 of this issue; Palke et al., 2019a, pp. 536-579 of this issue). After microscopic observation and UV-Vis spectroscopy, if needed, the trace element chemistry of these stones is measured by LA-ICP-MS (figure 12). At this point, a ruby needing an origin determination can be separated into either the marble hosted ruby group or the so-called high-iron ruby group based on its concentration of Fe; see Palke et al. (2019b), pp. 580-612 of this issue. LA-ICP-MS measurement is also the safeguard for detecting Be-diffused corundum (Emmett et al., 2003). Rubies and sapphires that have undergone this extreme treatment are not eligible for the geographic origin determination service at GIA. Additionally, the trace element profiles of rubies and sapphires are measured at GIA using internally developed matrixmatched corundum standards (Stone-Sundberg et al., 2017, and box A of this paper). Once the trace element chemistry data is collected, it is compared to GIA's database of stones with known provenance. For some stones, the number of deposits has proliferated so much in recent years and the amount of data collected is extensive enough that it can be difficult to

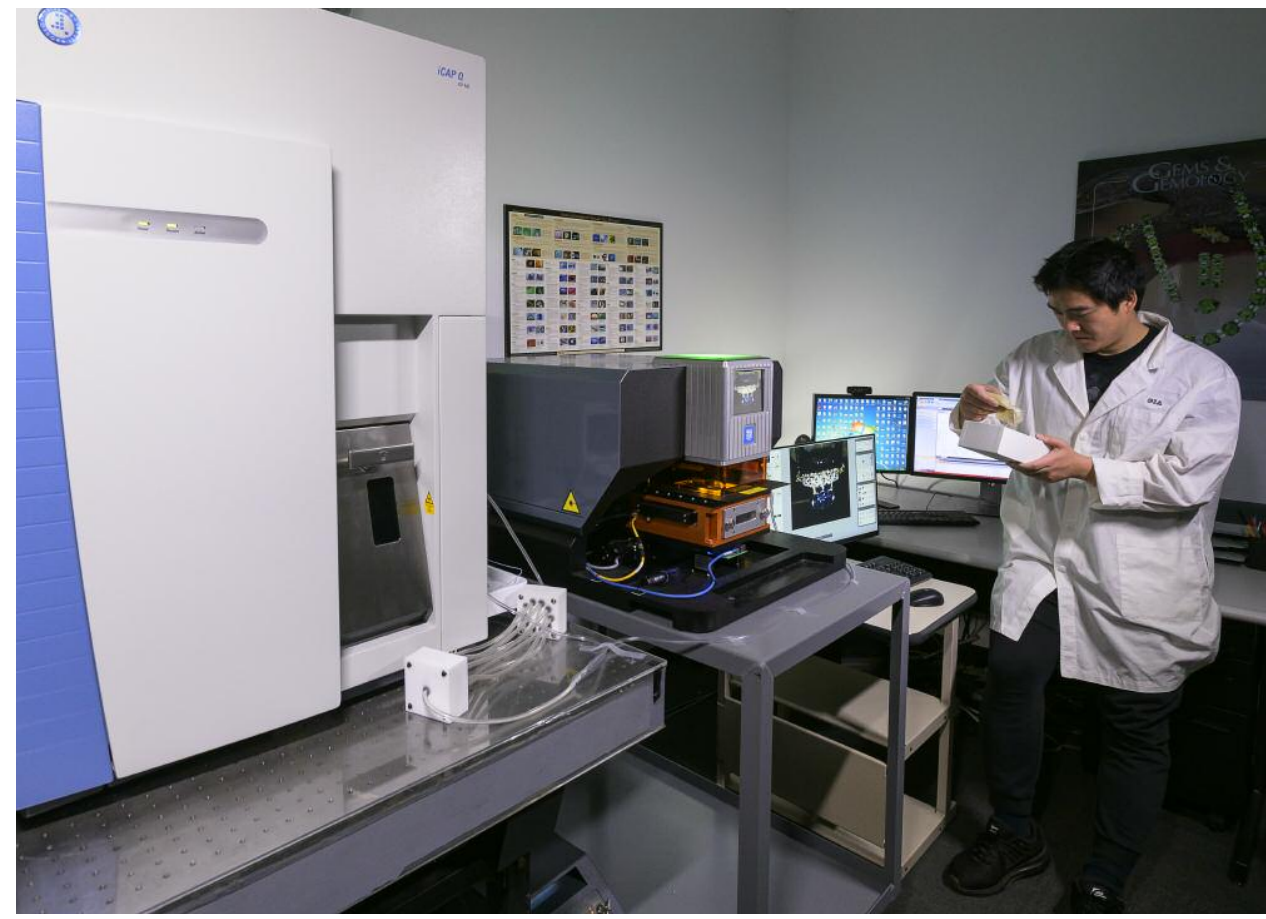

Figure 12. LA-ICP-MS instrument used in the GIA laboratory as part of the geographic origin determination process. The instrument on the left is a Thermo Fisher iCap ICP-MS, while the Elemental Scientific Lasers NWR 213 laser ablation unit is in the center of the photo. Photo by Kevin Schumacher. 
interpret an unknown sample's data on traditional two-dimensional plots. As mentioned in Palke et al. (2019a), pp. 536-579 of this issue, GIA employs a socalled selective plotting method to filter through the data and plot the unknown only against reference data with similar chemistry, making it much simpler to determine how to use the chemistry to assist in making an origin call.

At this point in the process, the full dataset has been collected for the submitted stone and a final decision must be made, taking into account all of the information available. In GIA laboratories, each stone and its corresponding data are always examined by at least two gemologists. If there are any discrepancies in their origin conclusions, the matter is discussed more fully, potentially involving additional gemologists, and all the gemologists involved must come together to reach an agreeable final decision. Ideally the evidence provided is sufficient to guide the geographic origin call to a specific location; however, in some cases when inclusion data or trace element chemistry are ambiguous, an inconclusive call is warranted. Once the gemologists have come to a conclusion on a geographic origin call, the stone can be finalized, an origin report is issued, and the stone is returned to its owner.

\section{APPLICATION OF ANALYTICAL METHODS FOR GEOGRAPHIC ORIGIN DETERMINATION}

Using traditional gemological techniques and advanced analytical instrumentation to collect robust and reliable data on gemstones can be extremely challenging. Often the biggest hurdle is to adapt analytical instruments originally designed for scientific specimens so that they analyze faceted gemstones in a nondestructive manner. However, sometimes the bigger challenge is to then take the information collected on a gemstone and synthesize the data in such a way as to aid in geographic origin determination. The following section provides a review of previous work approaching the origin determination problem using advanced analytical methods, with some examples of how the data produced has been used to deduce geographic origin for certain gemstones. Additionally, this special issue contains five articles that will detail GIA's methodology for geographic origin determination for blue sapphire, ruby, emerald, Paraíba-type tourmaline, and alexandrite (see the five gemstone-specific origin articles in this issue). These articles highlight the specific data collected for each material and the procedures that GIA gemologists follow for taking that data and making an origin call.

Corundum. Origin determination of corundum, especially blue sapphires, is challenging (Hainschwang and Notari, 2015; Palke et al., 2019a,b, pp. 536-579 and pp. 580-612 of this issue). To begin with, a number of microscopic features are common to corundum from many deposits. Therefore, inclusion characteristics must be considered very carefully in using this information to make an origin call, or to know when the inclusion information is too ambiguous to be used in origin determination. The most common inclusion in corundum is epitaxial rutile that is crystallographically aligned to the host corundum. Twinning is also a common feature observed globally in corundum along with boehmite intersection tubules associated with the intersection of twinning planes.

Blue sapphires from igneous sources such as Thailand, Cambodia, Ethiopia, Nigeria, and Australia may reveal inclusions that reflect their host rock and growth environment. Colorless feldspar crystals are one of the more common minerals observed in blue sapphires from igneous sources, but other mineral inclusions such as pyrochlore and columbite can be encountered, along with glassy melt inclusions that are highly indicative of igneous origin.

Sapphires from metamorphic deposits such as those in Myanmar, Sri Lanka, or some localities in Madagascar often contain negative crystals (voids with the crystallographic shape of the host corundum) that are filled with carbon dioxide fluid along with diaspore and sometimes graphite. Other solid minerals that are sometimes present are black cubes of uraninite, phlogopite mica, green spinel, or carbonate crystals. (Note that specific criteria used to distinguish blue sapphires based on their inclusion characteristics will be presented in a later article; Palke et al., 2019a, pp. 536-579 of this issue.)

Rarely does a single inclusion type narrow down a particular geographic origin. One notable exception is tourmaline and pargasite in sapphires from Kashmir. However, such inclusions are generally rare and cannot always be counted on to assist in an origin determination.

Rubies often contain inclusions that are representative of the geologic conditions or host rock that is responsible for their formation. For example, rubies from marble deposits often contain rounded grains of protogenetic calcite. They may also contain other mineral inclusions common to such an environment, includ- 


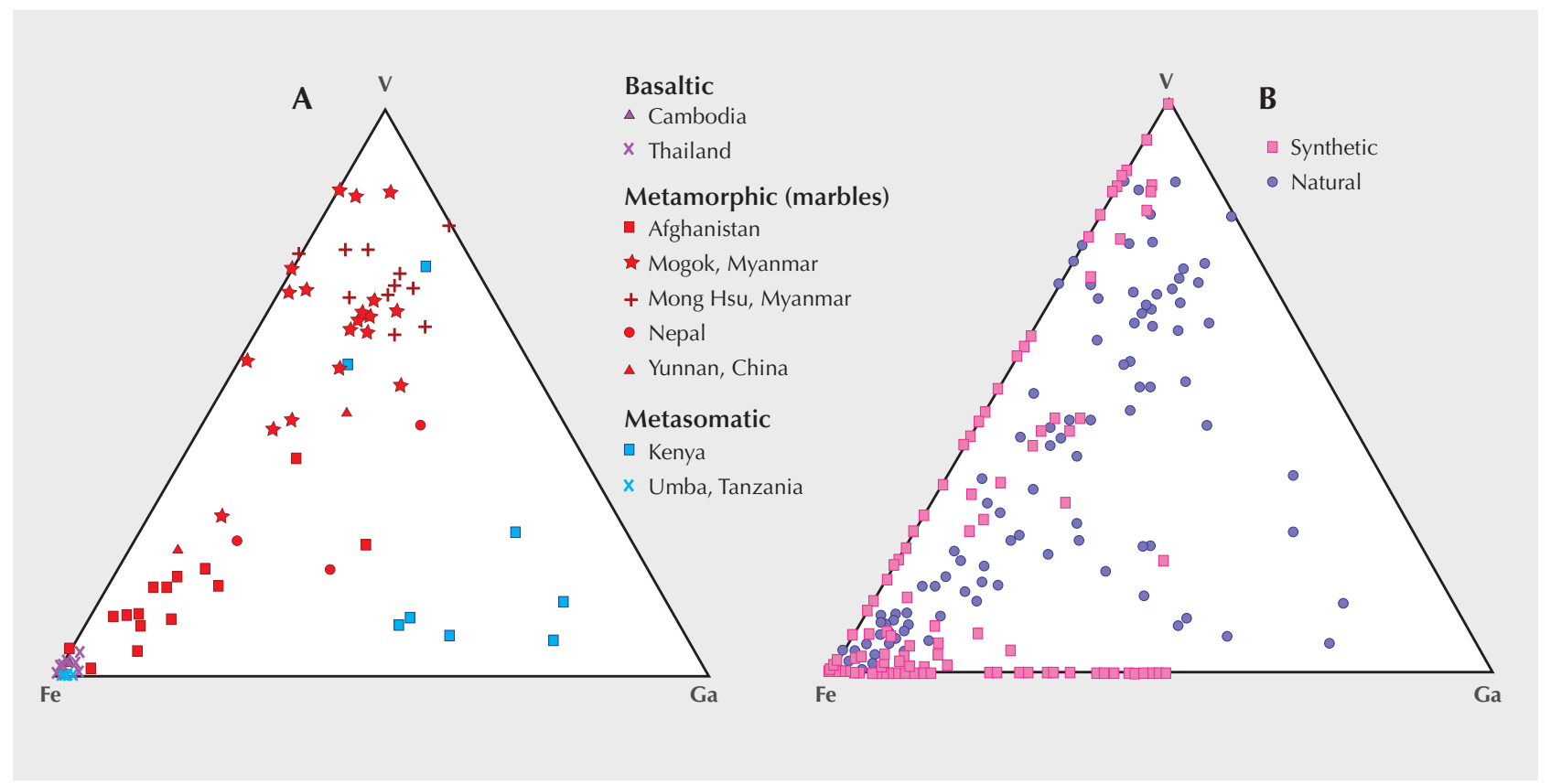

Figure 13. Chemical compositions of natural and synthetic rubies (from Giuliani et al., 2014a; modified from Muhlmeister et al., 1998). Gallium (Ga)-V-Fe diagrams (in wt.\%) for (A) natural ruby from different deposits, and (B) natural versus synthetic ruby.

ing graphite, apatite, phlogopite, or rutile. Rubies from basalt-related sources such as Thailand and Cambodia showcase an entirely different suite of inclusions that would not be present in stones from metamorphic or metasomatic deposits. Glassy melt inclusions are one of the most common and diagnostic inclusions for rubies of igneous origin, and these stones can also contain other minerals such as metal sulfides.

Rubies from metasomatic deposits such as those associated with amphibolites (for example, the Montepuez deposit in Mozambique) often host elongated rods of pargasite inclusions that reflect their geological genesis. (Note that specific criteria used to distinguish rubies of various geographic origins are presented in more detail in Palke et al. (2019b), pp. 580-612 of this issue.)

Trace elements are often used for origin determination of corundum because the species and concentrations are a function of (1) the source of the elements and (2) the genesis of the corundum-bearing deposits-i.e., crystallization from a magma (syenite) or from fluid-rock interaction through metamorphic reactions (amphibolite).

Origin determination of corundum based on chemical composition was initiated by Muhlmeister et al. (1998), who used energy-dispersive X-ray fluorescence to study trace elements in 283 natural and synthetic rubies from 14 localities and 12 manufac- turers. They found that the $\mathrm{Ti}, \mathrm{V}, \mathrm{Fe}$, and $\mathrm{Ga}$ contents, when considered together as a trace element signature, provided a means of separating nearly all synthetic from natural rubies. This signature could also be used to establish the geological environment in which a ruby formed, and thus imply a geographical origin (figure 13). In particular, they found that ruby from basalts (from Thailand and Cambodia) is Fe-rich and V- and Ga-poor, while marble-hosted ruby (from Afghanistan, Myanmar, Nepal, and China) is V-rich and Ga- and Fe-poor (except ruby from Afghanistan and some rubies from China, Nepal, and the Mogok mines in Myanmar). Metasomatic ruby found in different types of rocks and geological settings showed wide variation in trace element concentrations.

Peucat et al. (2007) analyzed corundum from different geological environments using LA-ICP-MS and proposed using the $\mathrm{Fe}, \mathrm{Ti}, \mathrm{Cr}, \mathrm{Ga}$, and $\mathrm{Mg}$ contents and ratios (such as $\mathrm{Ga} / \mathrm{Mg}$, Fe $/ \mathrm{Ti}, \mathrm{Fe} / \mathrm{Mg}$, and $\mathrm{Cr} / \mathrm{Ga}$ ) for origin determination of sapphires. In some cases, however, the use of these chemical diagrams is not useful for discriminating between geologic and geographic origin or either. Figure 14 shows the extreme diversity of trace element chemistry of plumasite-related sapphires from the Greek island of Naxos (Voudouris et al., 2019). They overlap the chemical domains of sapphires from Mogok, Umba, and Mer- 

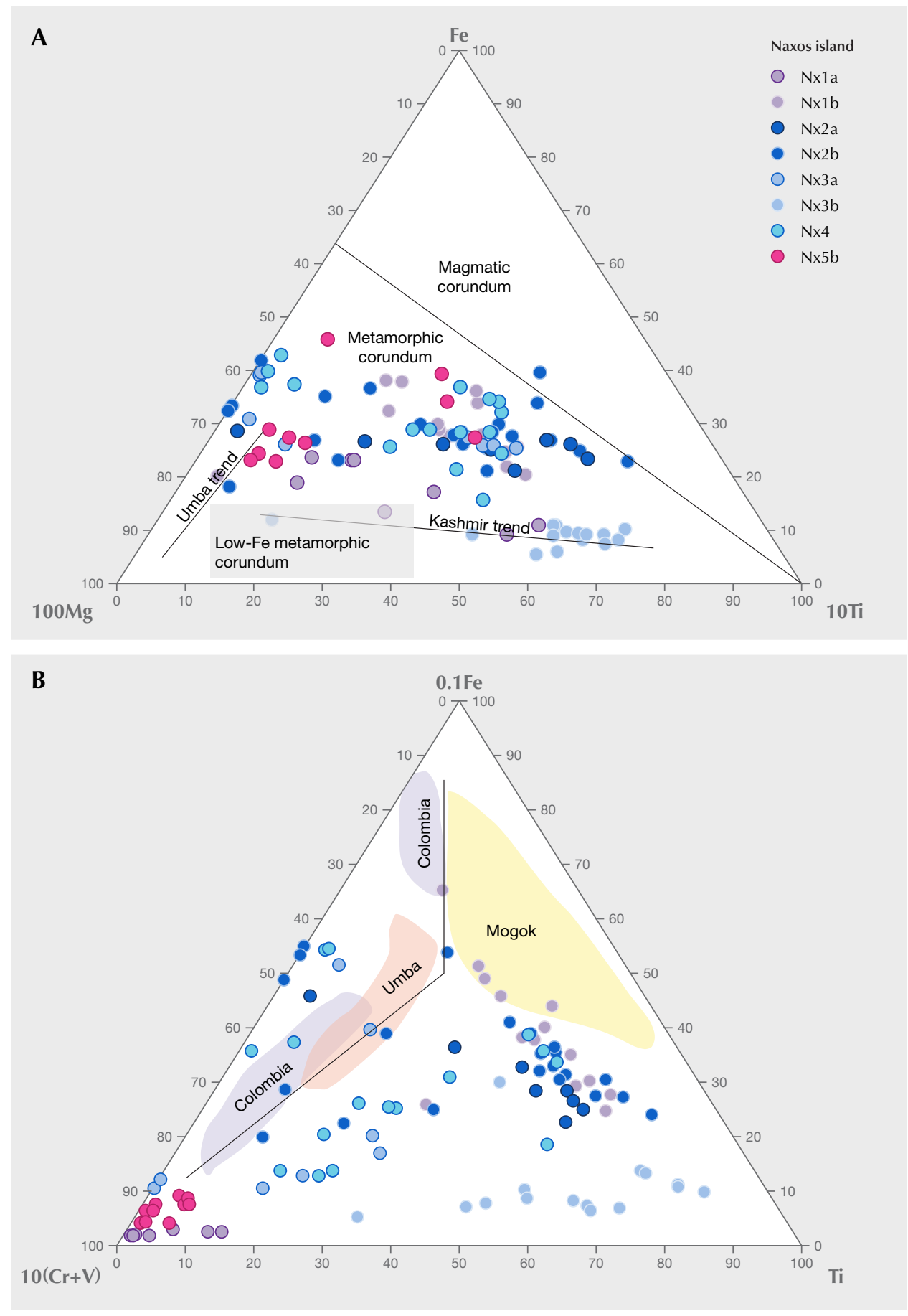

Figure 14. A: $100 \times M g-$ $\mathrm{Fe}-10 \times \mathrm{Ti}$ ternary discrimination diagram used for geological and geographical determination of blue sapphires. Modified from Voudouris et al. (2019). B: $0.1 \times \mathrm{Fe}-10 \times(\mathrm{Cr}+\mathrm{V})$ Ti ternary diagram showing the chemical fields for blue sapphires from different deposits. Trace element data from Naxos sapphires are plotted as well to show how sapphires from a single geographic locale can overlap with several other important geologically distinct sapphire-producing regions. caderes in Colombia, which are of different geological types. The Fe versus $\mathrm{Ga} / \mathrm{Mg}$ diagram in figure 15 corroborates this conclusion, with the majority of Naxos sapphires scattered in the field of metamorphic sapphires, but with some blue and pink sapphires overlapping the field of sapphires from Yogo Gulch in Montana, which are magmatic. The Naxos case illustrates the complexity and ambiguity of the use of trace element chemistry. Observations of GIA's colored stone reference database for blue sapphires suggest the overlap in metamorphic and magmatic blue sapphires may be more extensive than previously known; see Palke et al. (2019a), pp. 536-579 of this issue. The application of the parameters from Peucat et al. (2007) to blue sapphires associated with alkali basalts permitted discrimination of: (1) magmatic 


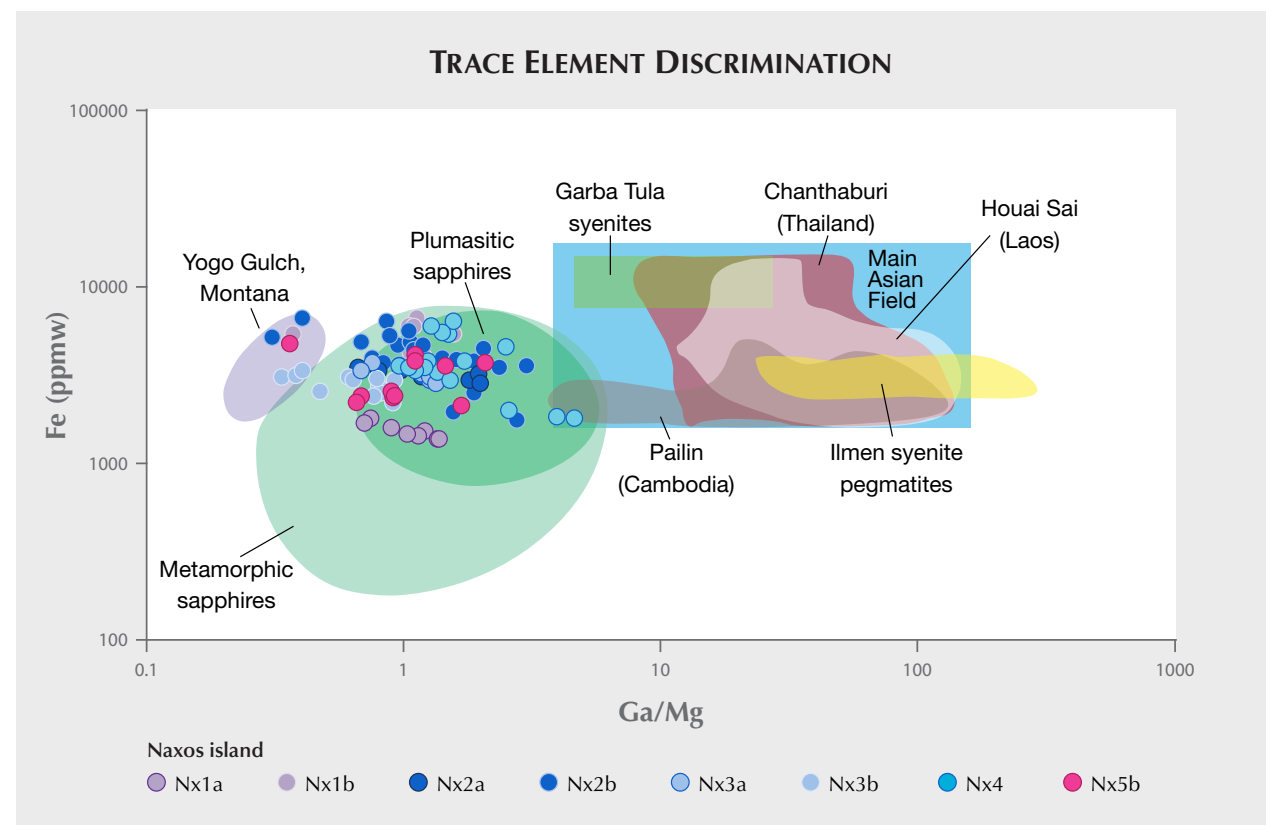

Figure 15. Ga/Mg versus Fe discrimination diagram for sapphires. From Voudouris et al. (2019).

blue sapphires that are Fe-rich (average 2000-11000 Fe ppmw), Ga-rich (>140 ppmw), and Mg-poor (<20 ppmw), with a Ga/Mg ratio > 10; and (2) metamorphic pastel blue sapphires that are Fe-poor (average Fe $<3000$ ppmw), Ga-poor (<75 ppmw), and Mg-rich (>60 ppmw), with a low average $\mathrm{Ga} / \mathrm{Mg}$ ratio $(<10)$. The chemical parameters defined for the pastel blue sapphires are similar to those determined for blue sapphires from metamorphic areas such as Myanmar (Mogok), Sri Lanka, and Madagascar (Ilakaka). Using the $\mathrm{Ga} / \mathrm{Mg}$ versus Fe diagram (figure 15), Voudouris et al. (2019) defined a field for sapphire-bearing plum- asites formed via metasomatism of pegmatites.

Giuliani et al. (2012) proposed the use of the $\mathrm{FeO}$ $\mathrm{Cr}_{2} \mathrm{O}_{3}-\mathrm{MgO}-\mathrm{V}_{2} \mathrm{O}_{3}$ versus $\mathrm{FeO}+\mathrm{TiO}_{2}+\mathrm{Ga}_{2} \mathrm{O}_{3}$ diagram (figure 16) for the classification of primary deposits. This diagram uses $\mathrm{Fe}(\mathrm{FeO})$ as a major or minor trace element in corundum; the FeO content permits discrimination of the two prominent types of ruby: Fe-poor rubies in marbles and Fe-rich rubies in maficultramafic rocks (Long et al., 2004). The second method used to discriminate ruby and sapphire is the addition (y-axis parameter) or subtraction from $\mathrm{FeO}$ ( $\mathrm{x}$-axis parameter) of trace elements associated prefer-

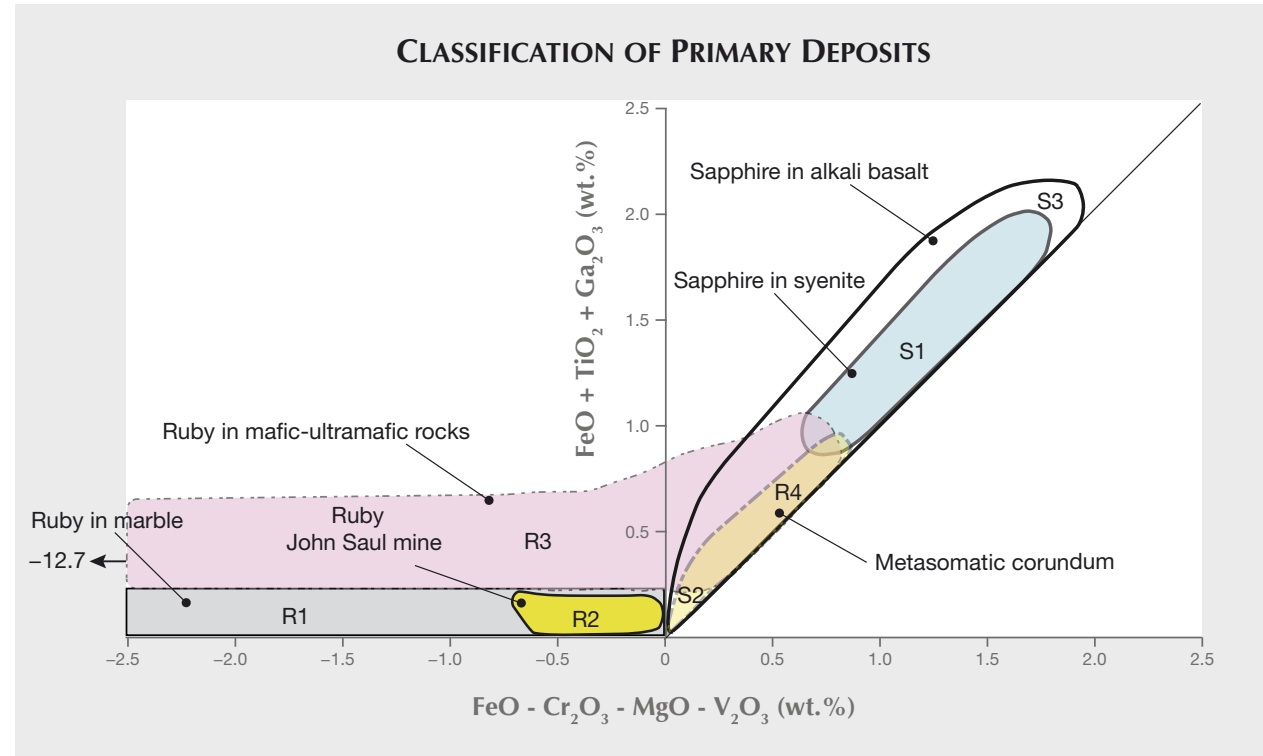

Figure 16. $\mathrm{An} \mathrm{FeO}-$ $\mathrm{Cr}_{2} \mathrm{O}_{3}-\mathrm{MgO}-\mathrm{V}_{2} \mathrm{O}_{3}$ versus $\mathrm{FeO}+\mathrm{TiO}_{2}+\mathrm{Ga}_{2} \mathrm{O}_{3}$ diagram (in wt. \%) for classifying corundum deposits (Giuliani et al., 2010; 2014a,b). The R1 field corresponds to ruby in marble, $R 2$ to ruby from the John Saul mine (Kenya), R3 to ruby from mafic and ultramafic rocks, $R 4$ to ruby from metasomatites, $S 1$ to sapphire from syenitic rocks, S2 to sapphire from metasomatites, and S3 to sapphire xenocrysts in alkali basalt and lamprophyre. 


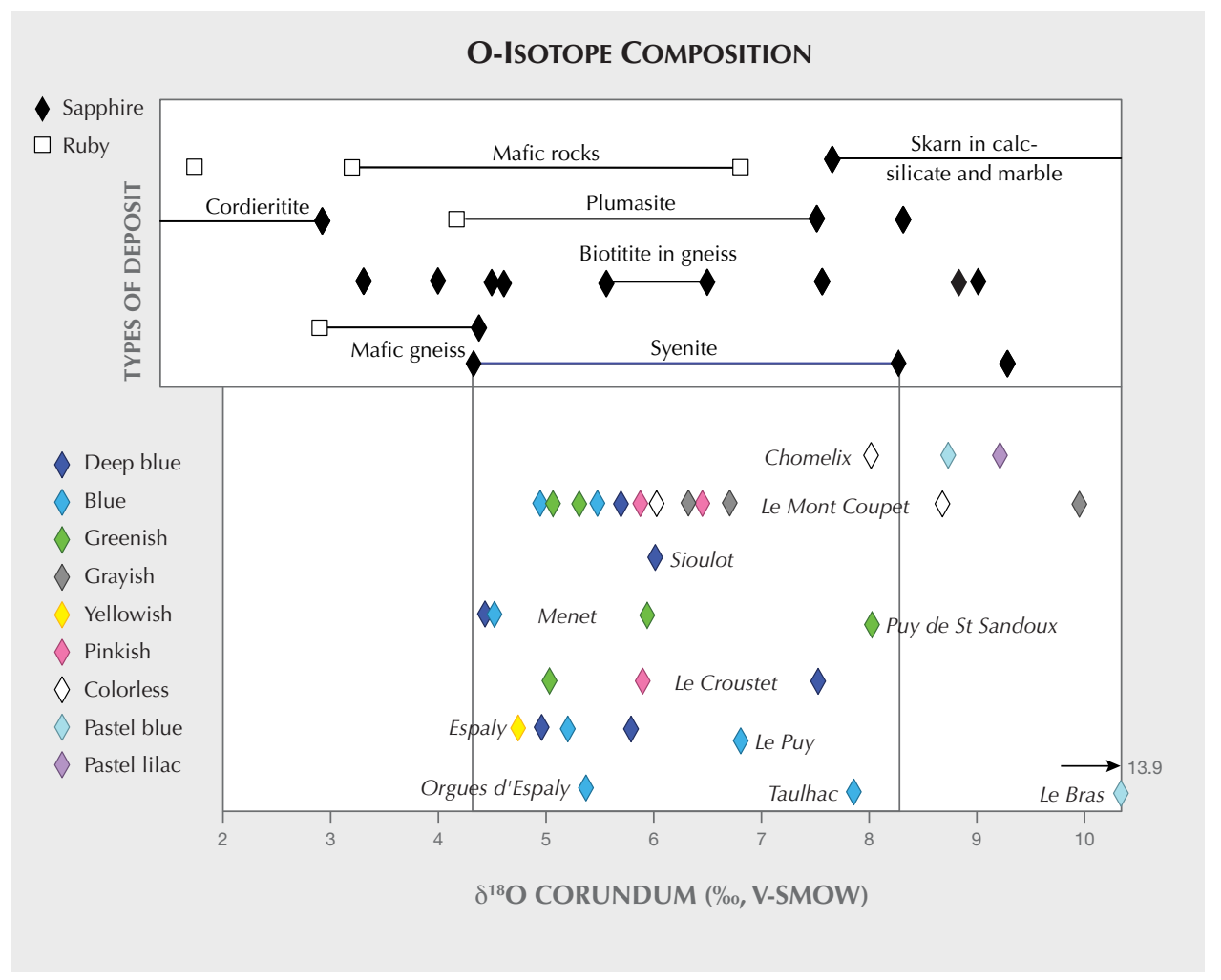

Figure 17. Oxygen isotope values of colored sapphires found in placers within the volcanic fields of the French Massif Central (Giuliani et al., 2009), with reference to the worldwide $\mathrm{O}$ isotopic database of corundum reported by Giuliani et al. $(2005,2007,2009)$.

The data are reported in the conventional delta notation $\left(\delta^{18} \mathrm{O}\right.$, expressed in per mil, $\%$ ) relative to $\mathrm{V}-$ SMOW (Vienna Standard Mean Ocean Water).

entially with ruby $\left(\mathrm{Cr}_{2} \mathrm{O}_{3}, \mathrm{~V}_{2} \mathrm{O}_{3}\right.$, and $\left.\mathrm{MgO}\right)$ or sapphire $\left(\mathrm{TiO}_{2}\right.$ and $\left.\mathrm{Ga}_{2} \mathrm{O}_{3}\right)$. The different types of corundum deposits are: for ruby, marble (R1), John Saul ruby mine (Kenya) type (R2), mafic and ultramafic rocks (R3), and metasomatites (R4); for sapphire, syenitic rocks (S1), metasomatites (S2), and xenocrysts in alkali-basalt and lamprophyre (S3). There is considerable overlap between the different domains (figure 16).

Oxygen makes up $47 \mathrm{wt}$ \% of the composition of corundum. The two main stable isotopes are ${ }^{18} \mathrm{O}$ and ${ }^{16} \mathrm{O}$, and data are reported in the conventional $\delta^{18} \mathrm{O}$ notation $\left({ }^{18} \mathrm{O} /{ }^{16} \mathrm{O}\right.$ ratio) as per mil (\%) relative to Vienna Standard Mean Ocean Water (VSMOW). The $\delta^{18} \mathrm{O}$ value in corundum presents an additional tool for deciphering its geological origin (Yui et al., 2003, 2006; Giuliani et al., 2005, 2007, 2009, 2014a; Zaw et al., 2006; Sutherland et al., 2009). As mantle and crustal rocks show distinct $\mathrm{O}$ isotope compositions, the $\delta^{18} \mathrm{O}$ value permits investigation of the origin and source of corundum. Giuliani et al. $(2007,2014 a)$ outlined the following principal genetic groups using $\delta^{18} \mathrm{O}$ values of sapphire and ruby and their host rocks: (1) for ruby: marble, desilicated pegmatite in marble, John Saul mine type, mafic-ultramafic rocks, mafic gneiss, and alkali basalt; (2) for sapphire: desilicated pegmatite and skarn vein in marble, syenite, desilicated pegmatite in mafic-ultramafic rocks, cordierite, biotite schist in gneiss, and alkali basalt and lamprophyres.
An example of the use of O-isotope composition to investigate geological origin is that of BGY (blue-greenyellow) sapphires associated with alkali basalts from the French Massif Central (Giuliani et al., 2009). The sapphire crystals are dominantly pastel blue, pastel lilac, and colorless, or they are blue, deep blue, greenish, grayish, yellowish, pinkish, and bronze-colored but milky. The O-isotope composition of the sapphires ranges from 4.4 to $13.9 \%$ (figure 17). Two distinct groups have been defined. The first shows a restricted isotopic range between 4.4 and $6.8 \%$ o $(\mathrm{n}=22$; mean $\delta^{18} \mathrm{O}=5.6 \pm 0.7 \%$ ) , falling within the worldwide range defined for BGY sapphires related to basaltic gem fields $\left(3.0<\delta^{18} \mathrm{O}<8.2 \%\right.$ o, $\left.\mathrm{n}=150\right)$, and overlapping the range defined for magmatic sapphires in syenite $\left(4.4<\delta^{18} \mathrm{O}<\right.$ $8.3 \%, \mathrm{n}=29$ ). The presence of inclusions of columbitegroup minerals, pyrochlore, Nb-bearing rutile, and thorite in these sapphires provides an additional argument for a magmatic origin. A second group, with an isotopic range between 7.6 and $13.9 \%$ o $(n=9)$, suggests a metamorphic sapphire source such as biotite schist in gneisses or skarns. These are metamorphic sapphires occurring in the granulite facies.

Emerald. Inclusions in emeralds can be used to determine geographic origin if they are from hydrothermal or schist-hosted environments. Hydrothermal emeralds, such as those from Colombia, often contain 
rhombohedral crystals of calcite and brassy yellow grains of pyrite. Schist-hosted emeralds, such as those from Zambia, Russia, and Ethiopia, commonly contain biotite mica and skeletal exsolution products of ilmenite and hematite.

Fluid inclusions in hydrothermal emeralds are jagged in shape because they result from secondary healing of fractures while still in the growth environment. Schist-hosted emeralds commonly show elongated, blocky primary fluid inclusions that reflect the crystal structure of the host beryl. Until recently, threephase (gas, liquid, solid) inclusions in emerald were considered a reliable indicator of Colombian origin. However, we now know that such inclusions are often seen in emeralds from other countries including Afghanistan (Panjshir Valley), China (Davdar), and Zambia (Musakashi) (Saeseaw et al., 2014, and references therein). Saeseaw et al. (2014) studied 84 samples from these deposits and Colombian deposits and reported that in most cases the combination of inclusion details, UV-Vis-NIR absorption data, and trace element chemistry can help determine the origin of emeralds with three- or multiphase inclusions.

Zwaan et al. (2012) studied emeralds from the Fazenda Bonfim region of Brazil and showed that they can be distinguished from those of other schist- and pegmatite-related commercial deposits, such as Kafubu in Zambia and Sandawana in Zimbabwe, by careful comparison of internal features and physical and chemical properties. They observed that the properties of the Fazenda Bonfim emeralds show the most overlap with emeralds from the Itabira district of Brazil, but can be differentiated by their significantly higher cesium $(\mathrm{Cs})$ and generally lower sodium $(\mathrm{Na})$ contents.

Schwarz and Klemm (2012) used LA-ICP-MS to obtain approximately 2,600 spot analyses of 40 major and trace elements from approximately 650 emerald samples from 21 different occurrences worldwide. They reported that the analyses provided a solid basis for genetic interpretations and (together with additional criteria) origin determination.

Schwarz (2015) continued with three case studies: Cordillera Oriental in Colombia, Santa Terezinha in Brazil, and Swat Valley in Pakistan. He noted that when the emeralds crystallized in very different geological-genetic environments (e.g., black shales in Colombia and phlogopite schists and carbonate-talc schists at Santa Terezinha), their mineralogical-gemological properties are also very different and they are easily distinguished. However, if the geological-genetic environment is the same or nearly identical for two deposits (as is the case with Santa Terezinha and Swat
Valley), the stones from them can sometimes show overlapping features. The separation of emeralds from such deposits can be difficult or even impossible.

Conversely, Hainschwang and Notari (2015) reported that the geographic origin of emerald can usually be determined with very high probability. In some cases, growth features and inclusions alone are sufficient to declare a geographic origin, but for many stones a combination of spectroscopic and chemical testing is used. For the latter, they identified the most important elements as $\mathrm{Cr}, \mathrm{V}, \mathrm{Fe}, \mathrm{Ga}, \mathrm{Sc}$, and $\mathrm{Cs}$, and sometimes rare earth elements. They noted that most emeralds from Colombia have very low $\mathrm{Fe}$ and high $\mathrm{Cr}$ and $\mathrm{V}$ contents, while many other deposits that are commercially important, such as Kafubu in Zambia, produce emeralds with much higher Fe content and typically much more $\mathrm{Cr}$ than V.

Ochoa et al. (2015) used X-ray fluorescence and infrared and Raman spectroscopy to study 530 samples from 35 mines in Colombia and Afghanistan and Brazil. Average Fe and Sc concentrations and a ternary Fe-Cr-V diagram could be used to distinguish between Colombian emeralds and those from Afghanistan and Brazil. They also used the ternary Fe-Cr-V diagram and $\mathrm{Cr} / \mathrm{V}$ ratio to distinguish samples from Chivor and Gachalá from other mines in Colombia. The $\mathrm{Cr} / \mathrm{V}$ ratio was used to distinguish Colombian gems from Brazilian, while the infrared data were able to separate Colombian from Afghan and Brazilian emeralds.

Aurisicchio et al. (2018) analyzed 17 emerald crystals from different worldwide deposits with EMP and SIMS. They then used principal component analysis (PCA) to study the major and trace element data and were able to discriminate each deposit with high reliability. They were also able to distinguish between emeralds related to granitic-pegmatitic intrusions and those occurring in environments controlled by tectonic events. Finally, Saeseaw et al. (2019), pp. 614-646 of this issue, details how trace element chemistry from LA-ICP-MS is used in GIA laboratories to determine geographic origin for emeralds.

Because $\mathrm{H}_{2} \mathrm{O}$ in the channels in beryl represents the original fluid composition from the time of formation (Aines and Rossman, 1984; Brown and Mills, 1986; Taylor et al., 1992), the $\delta \mathrm{D}$ (ratio of the two stable isotopes of hydrogen, ${ }^{1} \mathrm{H}$ and ${ }^{2} \mathrm{H}$; the latter is deuterium, hence " $\mathrm{D}$ ") in $\mathrm{H}_{2} \mathrm{O}$ released from beryl can be used to determine the source of the fluids from which the beryl grew (figure 18). This has been done for beryl from a number of deposits (Fallick and Barros, 1987; Taylor et al., 1992; Arif et al., 1996; Giuliani et al., 1997a,b, 1998, 2000b). In addition, 


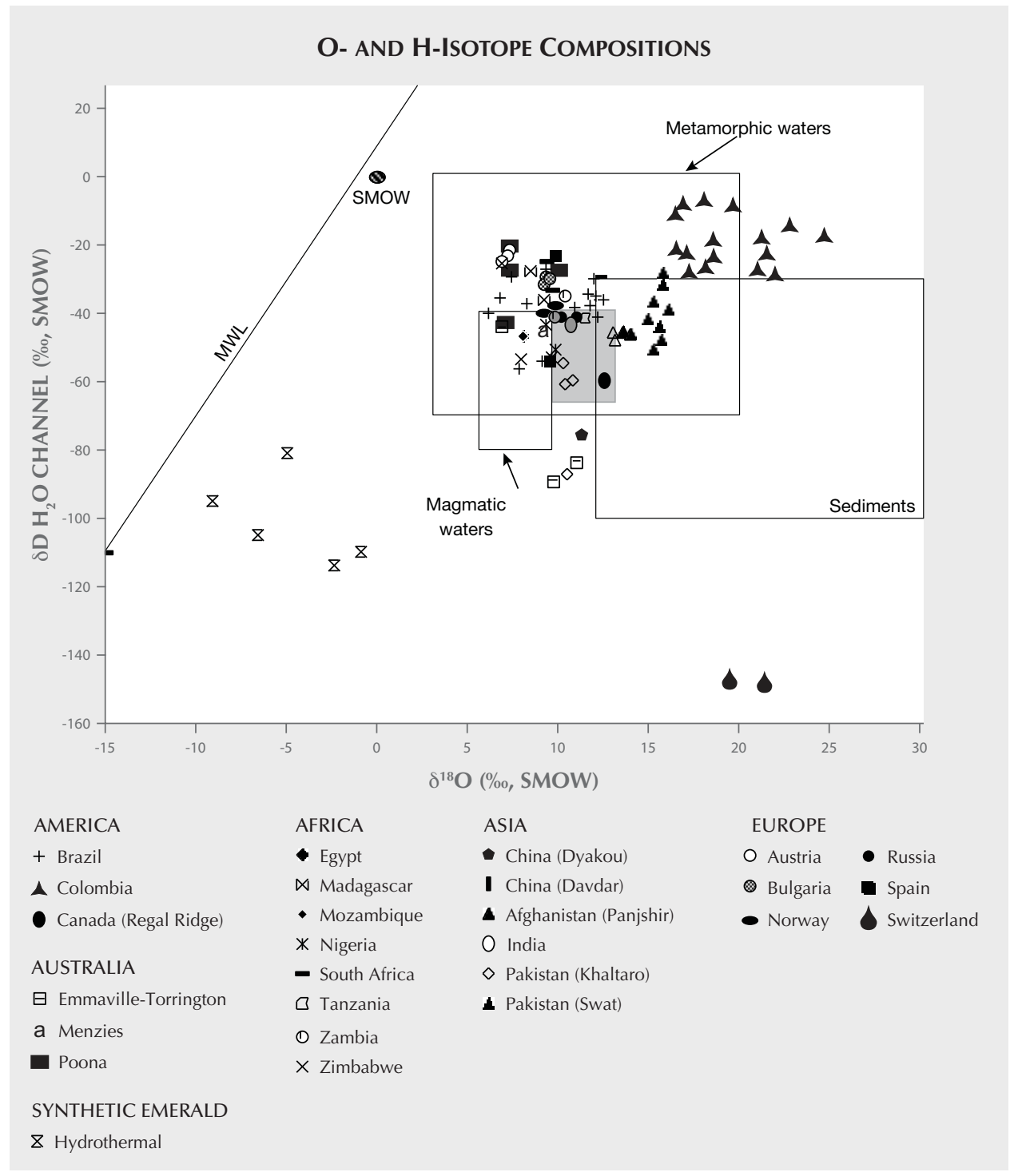

Figure 18. Channel $\delta^{18} \mathrm{O}$ versus $\delta \mathrm{D} \mathrm{H}_{2} \mathrm{O}$ for emerald worldwide (Marshall et al., 2017 and references therein). The isotopic compositional fields are from Sheppard (1986), including the extended (Cornubian) magmatic water box (gray). MWL = Meteoric Water Line, $S M O W=$ Standard Mean Ocean Water.

Giuliani et al. (2000a) used isotopic compositions of historical emerald artifacts to show that early artisans worked with emeralds originating from deposits supposedly discovered in the twentieth century, and that most of the high-quality emeralds cut in the eighteenth century in India originated from Colombia.

\section{CONCLUSIONS}

The last decade has seen unprecedented growth in the technological capacity of the modern gemological laboratory. Much of this technological advancement has resulted from the enormous pressure placed on gemological labs to provide geographic origin determination services for gemstones, especially corundum and emerald. The gem and jewelry industry often uses origin to set a stone's value. However, the geological forces that created many gems are sometimes apparently so similar across geographic localities that their physical and/or chemical properties can be difficult or essentially impossible to distinguish using the advanced instrumentation available to most gemological laboratories. GIA and other gemological research leaders are actively exploring the frontiers of new technology in analytical instrumentation to find additional criteria, such as isotopic measurements, photoluminescence analyses, and advanced statistical methods, to improve the accuracy of geographic origin determination. While there is hope in this regard, the geological origin for some stones and thus their physical properties are so similar that a definitive origin call cannot be made every time, even with the most advanced technological capabilities. 
ABOUT THE AUTHORS

Dr. Groat is a professor in the Department of Earth, Ocean and Atmospheric Sciences at the University of British Columbia in Vancouver. Dr. Giuliani is a senior researcher at Université Paul Sabatier, GET/IRD and Université de Lorraine, CRPG/CNRS, Vandoeuvre, France. Dr. Stone-Sundberg is a research scientist and technical editor of Gems \& Gemology. Mr. Sun is a research associate, Mr. Renfro is manager of colored stone identification, and Dr. Palke is a senior research scientist, at GIA in Carlsbad, California.

ACKNOWLEDGMENTS

Authors LAG and GG would like to thank GIA for inviting us to coauthor this contribution.

\section{REFERENCES}

Abdalla H.M., Mohamed F.H. (1999) Mineralogical and geochemical investigations of beryl mineralisation, Pan-African belt of Egypt: Genetic and exploration aspects. Journal of African Earth Sciences, Vol. 28, No. 3, pp. 581-598, http://dx.doi.org/ 10.1016/S0899-5362/99)00033-0

Abduriyim A., Kitawaki H. (2006) Applications of laser ablationinductively coupled plasma-mass spectrometry (LA-ICP-MS) to gemology. $G \uplus G$, Vol. 42, No. 2, pp. 98-118, http://dx.doi.org/ 10.5741/GEMS.42.2.98

Aines R.D., Rossman G.R. (1984) The high-temperature behavior of water and carbon dioxide in cordierite and beryl. American Mineralogist, Vol. 69, No. 3-4, pp. 319-327.

Alexandrov P., Giuliani G., Zimmerman J.L. (2001) Mineralogy, age and fluid geochemistry of the Rila Emerald deposits, Bulgaria. Economic Geology, Vol. 96, No. 6, pp. 1469-1476, http://dx.doi.org/10.2113/gsecongeo.96.6.1469.

Andrianjakavah P.R., Salvi S., Béziat D., Rakotondrazafy A.F.M., Giuliani G. (2009) Proximal and distal styles of pegmatite-related metasomatic emerald mineralization at Ianapera, southern Madagascar. Mineralium Deposita, Vol. 44, No. 7, pp. 817-835, http://dx.doi.org/10.1007/s00126-009-0243-5

Arif M., Fallick A.E., Moon A.E. (1996) The genesis of emeralds and their host rocks from Swat, northwestern Pakistan: A stable-isotope investigation. Mineralium Deposita, Vol. 31, No. 4, pp. 255-268, http://dx.doi.org/10.1007/BF02280790

Artioli R., Rinaldi R., Stahl K., Zanazzi P.F. (1993) Structure refinements of beryl by single-crystal neutron and X-ray diffraction. American Mineralogist, Vol. 78, No. 7, pp. 762-768.

Aurisicchio C., Conte A.M., Medeghini L., Ottolini L., De Vito C. (2018) Major and trace element geochemistry of emerald from several deposits: Implications for genetic models and classification schemes. Ore Geology Reviews, Vol. 94, pp. 351-366, http://dx.doi.org/10.1016/i.oregeorev.2018.02.001

Beus A.A., Mineev D.A. (1972) Some Geological and Geochemical Features of the Muzo-Coscuez Emerald Zone, Cordillera Oriental, Colombia. Empresa Colombiana de Minas, Bogotá, 55 pp.

Brand A.A., Groat L.A., Linnen R.L., Garland M.I., Breaks F.W., Giuliani G. (2009) Emerald mineralization associated with the Mavis Lake pegmatite group, near Dryden, Ontario. Canadian Mineralogist, Vol. 47, No. 2, pp. 315-336, http://dx.doi.org/10.3749/ canmin.47.2.315

Brown G.E. Jr., Mills B.A. (1986) High-temperature structure and crystal chemistry of hydrous alkali-rich beryl from the Harding pegmatite, Taos County, New Mexico. American Mineralogist, Vol. 71, No. 3-4, pp. 547-556.

Cesbron F., Lebrun P., Le Cléaćh J.M., Notari F., Grobon C., Deville J. (2002) Corindon et spinelles: histoire, cristallochimie, minéralogie, gemmologie, gisements, utilisations, synthèse. Minéraux et Fossiles, No. 15, CEDIM, Paris, 104 pp.

Conklin L.H. (2002) What is emerald - fact and opinion. extraLapis English, Vol. 2, pp. 72-73.

Emmett J.L., Scarratt K., McClure S.F., Moses T., Douthit T.R., Hughes R., Novak S., Shigley J.E. (2003) Beryllium diffusion of ruby and sapphire. GeG, Vol. 39, No. 2, pp. 84-135, http://dx.doi.org/10.5741/GEMS.39.2.84
Emmett J.L., Stone-Sundberg J., Guan Y., Sun Z. (2017) The role of silicon in the color of gem corundum. $G \uplus G$, Vol. 53, No. 1, pp. 42-47, http://dx.doi.org/10.5741/GEMS.53.1.42

Fallick A.E., Barros J.G. (1987) A stable-isotope investigation into the origin of beryl and emerald from the Porangatu deposits, Goiás state, Brazil. Chemical Geology: Isotope Geoscience Section, Vol. 66, No. 3-4, pp. 293-300, http://dx.doi.org/10.1016/ 0168-9622(87)90048-0

Fallick A.E., Jocelyn T., Donnelly M., Guy M., Behan C. (1985) Origin of agates in volcanic rocks from Scotland. Nature, Vol. 313 No. 6004, pp. 672-674, http://dx.doi.org/10.1038/313672a0

Garstone J.D. (1981) The geological setting and origin of emeralds from Menzies, Western Australia. Journal of the Royal Society of Western Australia, Vol. 64, pp. 53-64.

Gavrilenko E.V., Pérez B.C. (1999) Characterisation of emeralds from the Delbegetey deposit, Kazakhstan. In C.J. Stanley et al., Eds. Mineral Deposits: Processes to Processing Balkema. Rotterdam, The Netherlands, pp. 1097-1100.

Gavrilenko E.V., Calvo Pérez B., Castroviejo Bolibar R., Garcia Del Amo D. (2006) Emeralds from the Delbegetey deposit (Kazakhstan): Mineralogical characteristics and fluid-inclusion study. Mineralogical Magazine, Vol. 70, No. 2, pp. 159-173, http://dx.doi.org/10.1180/0026461067020321

Giuliani G., Fallick A.E. (2018) Isotope signatures of gem minerals. Wooshin, Vol. 5, pp. 2-9.

Giuliani G., Groat L.A. (2019) Geology of corundum and emerald gem deposits: A review. GせG, Vol. 55, No. 4, pp. 464-489, http://dx.doi.org/10.5741/GEMS.55.4.464

Giuliani G., France-Lanord C., Zimmermann J.L., et al. (1997a) Fluid composition, $\delta \mathrm{D}$ of channel $\mathrm{H}_{2} \mathrm{O}$, and $\delta^{18} \mathrm{O}$ of lattice oxygen in beryls: Genetic implications for Brazilian, Colombian, and Afghanistani emerald deposits. International Geology Review, Vol. 39, No. 5, pp. 400-424, http://dx.doi.org/10.1080/ 00206819709465280

Giuliani G., Cheilletz A., Zimmermann J.L., Ribeiro-Althoff A.M., France-Lanord C., Feraud G. (1997b) Les gisements d'émeraude du Brésil: genèse et typologie. Chronique de la Recherche Minière, Vol. 526, pp. 17-61.

Giuliani G., France-Lanord C., Coget P., Schwarz D., Cheilletz A., Branquet Y., Giard D., Martin-Izard A., Alexandrov P., Piat D.H. (1998) Oxygen isotope systematics of emerald: Relevance of its origin and geological significance. Mineralium Deposita, Vol 31, No. 5, pp. 513-519, http://dx.doi.org/10.1007/s001260050166

Giuliani G., Chaussidon M., Schubnel H.-J., et al. (2000a) Oxygen isotopes and emerald trade routes since antiquity. Science, Vol 287, No. 5453, pp. 631-633, http://dx.doi.org/10.1126/ science.287.5453.631

Giuliani G., Christian F., Cheilletz A., Coget P., Branquet Y., Laumonier B. (2000b) Sulfate reduction by organic matter in Colombian emerald deposits: Chemical and stable isotope $(\mathrm{C}$, $\mathrm{O}, \mathrm{H})$ evidence. Economic Geology, Vol. 95, No. 5, pp. 11291153, http://dx.doi.org/10.2113/95.5.1129

Giuliani G., Fallick A.E., Garnier V., France-Lanord C., Ohnenstetter D., Schwarz D. (2005) Oxygen isotope composition as a tracer for the origins of rubies and sapphires. Geology, Vol. 
33, No. 4, pp. 249-252, http://dx.doi.org/10.1130/G21261.1 Giuliani G., Ohnenstetter D., Garnier V, Fallick A.E., Rakotondrazafy A.F.M., Schwarz D. (2007) The geology and genesis of gem corundum deposits. In L.A. Groat, Ed., Geology of Gem Deposits, 1st ed. Mineralogical Association of Canada, Short Course Series 37, Yellowknife, Canada, pp. 23-78.

Giuliani G., Fallick A.E., Ohnenstetter D., Pegere G. (2009) Oxygen isotopes composition of sapphires from the French Massif Central: Implications for the origin of gem corundum in basaltic fields. Mineralium Deposita, Vol. 44, No. 2, pp. 221231, http://dx.doi.org/10.1007/s00126-008-0214-2

Giuliani G., Lasnier B., Ohnenstetter D., Fallick A.E., Pégère G. (2010) Les gisements de corindon de France. le Règne Minéral, Vol. 93, pp. 5-22.

Giuliani G., Ohnenstetter D., Fallick A.E., Groat L., Feneyrol J. (2012) Geographic origin of gems linked to their geographical history. InColor, No. 19, pp. 16-27.

Giuliani G., Ohnenstetter D., Fallick A.E., Groat L., Fagan J. (2014a) The geology and genesis of gem corundum deposits. In L.A. Groat, Ed., Geology of Gem Deposits, 2nd ed. Mineralogical Association of Canada, Short Course Series 44, pp. 29-112.

Giuliani G., Caumon, G., Rakotosamizanany S., et al. (2014b) Classification chimique des corindons par analyse factorielle discriminante : application à la typologie des gisements de rubis et saphirs. Revue de Gemmologie a.f.g., Vol. 188, pp. 14-22.

Giuliani G., Groat L.A., Marshall D., Fallick A.E., Branquet Y. (2019) Emerald deposits: A review and enhanced classification. Minerals, Vol. 9, No. 2, pp. 105-168, http://dx.doi.org/ $10.3390 / \min 9020105$

Graziani G., Gübelin E., Lucchesi S. (1983) The genesis of an emerald from the Kitwe District, Zambia. Neues Jahrbuch für Mineralogie Monatschefte, Vol. 1983, pp. 175-186.

Groat L.A., Marshall D.D., Giuliani G., et al. (2002) Mineralogical and geochemical study of the Regal Ridge showing emeralds, southeastern Yukon. Canadian Mineralogist, Vol. 40, No. 5, pp. 1313-1338, http://dx.doi.org/10.2113/gscanmin.40.5.1313

Groat L.A., Giuliani G., Marshall D.D., Turner D.J. (2008) Emerald deposits and occurrences: A review. Ore Geology Reviews, Vol. 34, No. 1-2, pp. 87-112, http://dx.doi.org/10.1016/j.oregeorev. 2007.09.003

Gübelin E.J. (1958) Emeralds from Sandawana. Journal of Gemmology, Vol. 6, No. 8, pp. 340-354.

Hainschwang T., Notari, F. (2015) Standards and protocols for emerald analysis in gem testing laboratories. InColor, pp. 106-114.

Hammarstrom J.M. (1989) Mineral chemistry of emeralds and some minerals from Pakistan and Afghanistan: An electron microprobe study. In A.H. Kazmi, L.W. Snee, Eds., Emeralds of Pakistan. Van Nostrand Reinhold, New York, pp. 125-150.

Hänni H.A. (1994) Origin determination for gemstones: Possibilities, restrictions and reliability. Journal of Gemmology, Vol. 24, No. 3, pp. 139-148.

Hänni H.A., Klein H.H. (1982) Ein Smaragdvorkommen in Madagaskar. Zeitschrift der Deutschen Gemmologischen Gesellschaft, Vol. 21, pp. 71-77.

Hickman A.C.J. (1972) The Miku emerald deposit. Geological Survey of Zambia, Economic Report, Vol. 27, pp. 35.

Hughes R.W. (1997) Ruby «) Sapphire. RWH Publishing, Boulder, Colorado, 512 pp.

Hughes R.W., Manorotkul W., Hughes E.B. (2017) Ruby and Sapphire: A Gemologist's Guide, RWH Publishing/Lotus Publishing, Thailand, $738 \mathrm{pp}$.

Kovaloff P. (1928) Geologist's report on Somerset emeralds. South African Mining and Engineering Journal, Vol. 39, pp. 101-103.

Kozlowski A., Metz P., Jaramillo H.A.E. (1988) Emeralds from Somondoco, Colombia: Chemical composition, fluid inclusion and origin. Neues Jahrbuch für Mineralogie Abhandlungen, Vol. 59 , pp. $23-49$

Lake D.J., Groat L., Falck H., Cempirek J., Kontak D., Marshall D., Giuliani G., Fayek M. (2017) Genesis of emerald-bearing quartz veins associated with the Lened W-skarn mineralization, Northwest Territories, Canada. Canadian Mineralogist, Vol. 55 No. 4, pp. 561-593, http://dx.doi.org/10.3749/canmin.1700025

Leitmeier H. (1937) Das Smaragdvorkommen in Habachtal in Salzburg und seine Mineralien. Zeitschrift für Kristallographie, Mineralogie und Petrographie, Vol. 49, No. 4-5, pp. 245-368, http://dx.doi.org/10.1007/BF02945601

Long P.V., Vinh H.Q., Garnier V., et al. (2004) Gem corundum deposits in Vietnam. Journal of Gemmology, Vol. 29, No. 3, pp. 129-147.

Loughrey L., Marshall D., Jones P., Millsteed P., Main A. (2012) Pressure-temperature-fluid constraints for the Emmaville-Torrington emerald deposit, New South Wales, Australia: Fluid inclusion and stable isotope studies. Open Geosciences, Vol. 4, No. 2, pp. 287-299, http://dx.doi.org/10.2478/s13533-011-0056-9

Loughrey L., Marshall D., Ihlen P., Jones P. (2013) Boiling as a mechanism for colour zonations observed at the Byrud emerald deposit, Eidsvoll, Norway: Fluid inclusion, stable isotope and Ar-Ar studies. Geofluids, Vol. 13, No. 4, pp. 542-558, http://dx.doi.org/10.1111/gfl.12051

Marshall D.D., Groat L.A., Falck H., et al. (2004) The Lened emerald prospect, Northwest Territories, Canada: Insights from fluid inclusions and stable isotopes, with implications for Northern Cordilleran emerald. Canadian Mineralogist, Vol. 42, No. 5, pp. 1523-1539, http://dx.doi.org/10.2113/gscanmin.42.5.1523

Marshall D., Pardieu V., Loughrey L., Jones P., Xue G. (2012) Conditions for emerald formation at Davdar, China: Fluid inclusion, trace element and stable isotope studies. Mineralogical Magazine, Vol. 76, No. 1, pp. 213-226, http://dx.doi.org/ 10.1180/minmag.2012.076.1.213

Marshall D., Downes P.J., Ellis S., Greene R., Loughrey L., Jones, P. (2016) Pressure-temperature-fluid constraints for the Poona emerald deposits, Western Australia: Fluid inclusion and stable isotope studies. Minerals, Vol. 6, No. 4, pp. 130-152, http://dx.doi.org/10.3390/min6040130

Marshall D., Meisser N., Ellis S., Jones P., Bussy F., Mumenthaler T. (2017) Formational conditions for the Binntal emerald occurrence, Valais, Switzerland: Fluid inclusion, chemical composition and stable isotope studies. Canadian Mineralogist, Vol. 55 No. 4, pp. 725-741, http://dx.doi.org/10.3749/canmin.1600090

Martin H.J. (1962) Some observations on southern Rhodesian emeralds and chrysoberyl. Journal of the Chamber of Mines, Vol. 4, pp. 34-38.

Muhlmeister S., Fritsch E., Shigley J.E., Devouard B., Laurs B.M. (1998) Separating natural and synthetic rubies on the basis of trace-element chemistry. GÆ G, Vol. 34, No. 2, pp. 80-101, http://dx.doi.org/10.5741/GEMS.34.2.80

Nassau K. (1983) The Physics and Chemistry of Color: The Fifteen Causes of Color. John Wiley and Sons, New York, 480 pp.

Notari F., Grobon C.C. (2002) Gemmologie du corindon et du spinelle. In Corindons et Spinelles, Minéraux et Fossiles 15, Paris, France, pp. 48-59.

Ochoa C.J.C., Daza M.J.H., Fortaleche D., Jiménez J.F. (2015) Progress on the study of parameters related to the origin of Colombian emeralds. InColor, pp. 88-97.

Otero Muñoz G., Barriga Villalba A.M. (1948) Esmeraldas de Colombia. Banco de la Republica, Bogotá.

Ottaway T.L. (1991) The geochemistry of the Muzo emerald deposit, Colombia. M.Sc. thesis, University of Toronto.

Palke A.C., Saeseaw S., Renfro N.D., Sun Z., McClure S.F. (2019a) Geographic origin determination of blue sapphire. GÆ G, Vol. 55, No. 4, pp. 536-579, http://dx.doi.org/10.5741/GEMS.55.4.536

Palke A.C., Saeseaw S., Renfro N.D., Sun Z., McClure S.F. (2019b) Geographic origin determination of ruby. $G \uplus G$, Vol. 55, No. 4, pp. 580-612, http://dx.doi.org/10.5741/GEMS.55.4.580

Peretti A., Günther D. (2002) The color enhancement of fancy sapphires with a new heat-treatment technique (Part A): Inducing color zoning by internal migration and formation of color centers. Contributions to Gemology, Vol. 11, pp. 1-48.

Petrusenko S., Arnaudov V., Kostov I. (1966) Emerald pegmatite from 
the Urdini Lakes, Rila Mountains. Annuaire de l'Université de Sofia Faculté de Géologie et Géographie. Vol. 59, pp. 247-268.

Peucat J.J., Ruffault P., et al. (2007) Ga/Mg ratios as a new geochemical tool to differentiate magmatic from metamorphic blue sapphires. Lithos, Vol. 98, No. 1-4, pp. 261-274, http://dx.doi.org/10.1016/j.lithos.2007.05.001

Rondeau B., Fritsch E., Peucat J.J., Nordru F.S., Groat L.A. (2008) Characterization of emeralds from a historical deposit: Byrud (Eidsvoll), Norway. GせG, Vol. 44, No. 2, pp. 108-122, http://dx.doi.org/10.5741/GEMS.44.2.108

Saeseaw S., Pardieu V., Sangsawong S. (2014) Three-phase inclusions in emerald and their impact on origin determination. $G \uplus G$, Vol. 50, No. 2, pp. 114-132, http://dx.doi.org/10.5741/GEMS.50.2.114

Saeseaw S., Renfro N.D., Palke A.C., Sun Z., McClure S.F. (2019) Geographic origin determination of emerald. $G \uplus G$, Vol. 55, No. 4, pp. 614-646, http://dx.doi.org/10.5741/GEMS.55.4.614

Santiago J.S., Souza V.S., et al. (2018) Emerald from the Fazenda Bonfim deposit, northeastern Brazil: Chemical, fluid inclusions and oxygen isotope data. Brazilian Journal of Geology, Vol. 48, No. 3, pp. 457-472, http://dx.doi.org/10.1590/2317-4889201820170130

Schwarz D. (1991) Australian emeralds. Australian Gemmologist, Vol. 17, No. 12, pp. 488-497.

Schwarz D. (2015) The geographic origin determination of emeralds. InColor, pp. 98-105.

Schwarz D., Klemm L. (2012) Chemical signature of emerald. 34th International Geological Congress, Abstract 2812.

Schwarz D., Schmetzer K. (2002) The definition of emerald. extraLapis English, Vol. 2, pp. 74-78.

Schwarz D., Kanis J., Kinnaird J. (1996) Emerald and green beryl from central Nigeria. Journal of Gemmology, Vol. 25, No. 2, pp. 117-141.

Schwarz D., Pardieu V., Saul J.M., et al. (2008) Rubies and sapphires from Winza, central Tanzania. GÆ G, Vol. 44, No. 4, pp. 322-347, http://dx.doi.org/10.5741/GEMS.44.4.322

Sheppard S.M.F. (1986) Characterization and isotopic variations in natural waters. In J.W. Valley, H.P. Taylor, J.R. O'Neil, Eds., Stable Isotopes in High Temperature Geological Processes. Mineralogical Association of America, Chantilly, Virginia, Vol. 16, pp. $165-183$.

Simpson E.S. (1948) Minerals of Western Australia, Vol. 1. Government Printer, Perth, Australia, pp. 195-207.

Stone-Sundberg J., Thomas T., Sun Z., Guan Y., Cole Z., Equall R., Emmett J.L. (2017) Accurate reporting of key trace elements in ruby and sapphire using matrix-matched standards. $G \uplus G$, Vol. 53, No. 4, pp. 438-451, http://dx.doi.org/10.5741/GEMS.53.4.438

Sunagawa I., Bernhardt H.J., Schmetzer K. (1999) Texture formation and element partitioning in trapiche ruby. Journal of Crystal Growth, Vol. 206, No. 4, pp. 322-330, http://dx.doi.org/ 10.1016/S0022-0248/99|00331-0

Sutherland F.L., Zaw K., Meffre S., Giuliani G., Fallick A.E., Webb G.B. (2009) Gem-corundum megacrysts from east Australian basalt fields: Trace elements, oxygen isotopes and origins. Australian Journal of Earth Sciences, Vol. 56, No. 7, pp. 1003-1022, http://dx.doi.org/10.1080/08120090903112109

Taylor R.P., Fallick A.E., Breaks F.W. (1992) Volatile evolution in
Archean rare-element granitic pegmatites: evidence from the hydrogen-isotopic composition of channel $\mathrm{H}_{2} \mathrm{O}$ in beryl. Canadian Mineralogist, Vol. 30, pp. 877-893.

Vapnik Y., Sabot B., Moroz I. (2005) Fluid inclusions in Ianapera emerald, Southern Madagascar. International Geology Review, Vol. 47, No. 6, pp. 647-662, http://dx.doi.org/10.2747/0020 6814.47.6.647

Vapnik Y., Moroz I., Eliezri I. (2006) Formation of emeralds at pegmatite-ultramafic contacts based on fluid inclusions in Kianjavato emerald, Mananjary deposits, Madagascar. Mineralogical Magazine, Vol. 70, No. 2, pp. 141-158, http://dx.doi.org/ $10.1180 / 0026461067020320$

Vertriest W., Palke A., Renfro N.D. (2019) Field gemology: Building a research collection and understanding the development of gem deposits. Ge G, Vol. 55, No. 4, pp. 490-511, http://dx.doi.org/10.5741/GEMS.55.4.490

Vlasov K.A., Kutakova E.I. (1960) Izumrudnye Kopi. Moscow Akademiya Nauk SSGR. Moscow, Russia, 252 pp.

Voudouris P., Mavrogonatos C., Graham I., Giuliani G., et al. (2019) Gem corundum deposits of Greece: Geology, mineralogy and genesis. Minerals, Vol. 9, No. 1, pp. 49-90, http://dx.doi.org/ $10.3390 / \min 9010049$

Wang W., Hall M., Shen A.H., Breeding C.M. (2006) Developing corundum standards for LA-ICP-MS trace-element analysis. $G \uplus G$, Vol. 42, No. 3, pp. 105-106.

Yui T.F., Zaw K., Limkatrun P. (2003) Oxygen isotope composition of the Denchai sapphire, Thailand: A clue to its enigmatic origin. Lithos, Vol. 67, No. 1-2, pp. 153-161, http://dx.doi.org/ 10.1016/S0024-4937/02)00268-2

Yui T.F., Wu C.-M., Limkatrun P., et al. (2006) Oxygen isotope studies on placer sapphire and ruby in the Chanthaburi-Trat alkali basaltic gemfield, Thailand. Lithos, Vol. 86, No. 3-4, pp. 197-211, http://dx.doi.org/10.1016/j.lithos.2005.06.002

Zambonini F., Caglioto V. (1928) Ricerche chimiche sulla rosterite di San Piero in Campo (Isola d'Elba) e sui berilli in generale. Gazzetta Chimica Italiana, Vol. 58, pp. 131-152.

Zaszczak J.A. (2013) Word to the wise: Raman spectroscopy in the identification and study of minerals. Rocks 4 ) Minerals, Vol. 88, No. 2, pp. 184-189, http://dx.doi.org/10.1080/00357529. 2013.763698

Zaw K., Sutherland F.L., Dellapasqua F., et al. (2006) Contrasts in gem corundum characteristics, eastern Australian basaltic fields: Trace elements, fluid/melt inclusions and oxygen isotopes. Mineralogical Magazine, Vol. 70, No. 6, pp. 669-687, http://dx.doi.org/10.1180/0026461067060356

Zwaan J.C. (2006) Gemmology, geology and origin of the Sandawana emerald deposits, Zimbabwe. Scripta Geologica, Vol. 131, pp. 1-211

Zwaan J.C., Seifert A.V., Vrána S., Laurs B.M., Anckar B., Simmons W.B., et al. (2005) Emeralds from the Kafubu area, Zambia. Ge)G, Vol. 41, No. 2, pp. 116-148, http://dx.doi.org/ 10.5741/GEMS.41.2.116

Zwaan J.C., Jacob D.E., Häger T., et al. (2012) Emeralds from the Fazenda Bonfim region, Rio Grande do Norte, Brazil. Ge G, Vol. 48, No. 1, pp. 2-17, http://dx.doi.org/10.5741/GEMS.48.1.2

For online access to all issues of GEMS \& GEMOLOGY from 1934 to the present, visit: 